\section{OPEN ACCESS}

Edited by:

Anas Ghadouani

University of Western Australia,

Australia

Reviewed by:

Gael P. R. Dur,

Shizuoka University, Japan

Kim Sarah Bernard,

Oregon State University, United States

*Correspondence:

Tor Knutsen

tor.knutsen@imr.no; tor.knutsen@hi.no

Specialty section:

This article was submitted to Coastal Ocean Processes,

a section of the journal

Frontiers in Marine Science

Received: 27 June 2017

Accepted: 20 April 2018

Published: 23 May 2018

Citation:

Knutsen T, Hosia A, Falkenhaug T,

Skern-Mauritzen $R$, Wiebe $P H$,

Larsen RB, Aglen A and Berg E (2018)

Coincident Mass Occurrence of

Gelatinous Zooplankton in Northern Norway. Front. Mar. Sci. 5:158.

doi: 10.3389/fmars.2018.00158

\title{
Coincident Mass Occurrence of Gelatinous Zooplankton in Northern Norway
}

\section{Tor Knutsen ${ }^{1 *}$, Aino Hosia ${ }^{2}$, Tone Falkenhaug ${ }^{1}$, Rasmus Skern-Mauritzen ${ }^{3}$, Peter H. Wiebe ${ }^{4}$, Roger B. Larsen ${ }^{5}$, Asgeir Aglen ${ }^{6}$ and Erik Berg ${ }^{7}$}

${ }^{1}$ Research Group Plankton, Institute of Marine Research, Bergen, Norway, ${ }^{2}$ Department of Natural History, University Museum of Bergen, University of Bergen, Bergen, Norway, ${ }^{3}$ Research Group Disease and Pathogen Transmission, Institute of Marine Research, Bergen, Norway, ${ }^{4}$ Biology Department, Woods Hole Oceanographic Institution, Woods Hole, MA, United States, ${ }^{5}$ UIT, The Norwegian College of Fishery Science, The Arctic University of Norway, Tromsø, Norway, ${ }^{6}$ Research Group Demersal Fish, Institute of Marine Research, Bergen, Norway, ${ }^{7}$ Research Group Deep-water Species and Cartilaginous Fish, Institute of Marine Research, Bergen, Norway

In autumn 2015, several sources reported observations of large amounts of gelatinous material in a large north Norwegian fjord system, either caught when trawling for other organisms or fouling fishing gear. The responsible organism was identified as a physonect siphonophore, Nanomia cara, while a ctenophore, Beroe cucumis, and a hydromedusa, Modeeria rotunda, were also registered in high abundances on a couple of occasions. To document the phenomena, we have compiled a variety of data from concurrent fisheries surveys and local fishermen, including physical samples, trawl catch, and acoustic data, photo and video evidence, and environmental data. Because of the gas-filled pneumatophore, characteristic for these types of siphonophores, acoustics provided detailed and unique insight to the horizontal and vertical distribution and potential abundances $\left(\sim 0.2-20\right.$ colonies $\left.\cdot \mathrm{m}^{-3}\right)$ of $\mathrm{N}$. cara with the highest concentrations observed in the near bottom region at $\sim 320 \mathrm{~m}$ depth in the study area. This suggests that these animals were retained and accumulated in the deep basins of the fjord system possibly blooming here because of favorable environmental conditions and potentially higher prey availability compared to the shallower shelf areas to the north. Few cues as to the origin and onset of the bloom were found, but it may have originated from locally resident siphonophores. The characteristics of the deep-water masses in the fjord basins were different compared to the deep water outside the fjord system, suggesting no recent deep-water import to the fjords. However, water-masses containing siphonophores (not necessarily very abundant), may have been additionally introduced to the fjords at intermediate depths, with the animals subsequently trapped in the deeper fjord basins. The simultaneous observations of abundant siphonophores, hydromedusae, and ctenophores in the Lyngen-Kvænangen fjord system are intriguing, but difficult to provide a unified explanation for, as the organisms differ in their biology and ecology. Nanomia and Beroe spp. are holopelagic, while $M$. rotunda has a benthic hydroid stage. The species also have different trophic ecologies and dietary preferences. Only by combining information from acoustics, trawling, genetics, and local fishermen, were the identity, abundance, and the vertical and horizontal distribution of the physonect siphonophore, N. cara, established.

Keywords: jellyfish bloom, genetics, acoustics, Nanomia, North Norwegian fjords, gelatinous zooplankton 


\section{INTRODUCTION}

Gelatinous predators, such as pelagic cnidarians and ctenophores, are a ubiquitous component of marine pelagic communities. Typical for both pelagic cnidarians and ctenophores, often jointly referred to as jellies, is that many species can sporadically and often unpredictably occur in high abundances, colloquially referred to as jellyfish blooms. Such mass occurrences of jellies, can indeed be true blooms, caused by the combination of favorable environmental conditions and life history events resulting in a rapid increase in population numbers. They can also represent aggregations of individuals brought together by physical forcing of water movements and bottom topography (Arai, 1992; Graham et al., 2001), or behavioral responses. It is often not immediately apparent which processes are responsible for an observed high-density event.

Regardless of the cause, mass occurrences of pelagic cnidarians or ctenophores can have severe ecosystem impacts, including diverting carbon flow to gelatinous predators and initiating trophic cascades with consequences for the lower trophic levels (Condon et al., 2011; Oguz et al., 2012), affecting nutrient regeneration and productivity (Pitt et al., 2009; Hosia et al., 2015), and influencing the vertical flux of carbon (Lebrato et al., 2013; Sweetman and Chapman, 2015). Aggregations of jellies also have socio-economic costs and may negatively impact or hinder fisheries, cause losses to aquaculture, clog water intakes of power and desalination plants, or cause a problem for the tourism industry (Purcell et al., 2007). Jellies are thus often considered a nuisance and concern has been raised that human activities could be promoting higher abundances and more frequent bloom events (Mills, 2001; Richardson et al., 2009; Brotz et al., 2012). While several plausible mechanisms for how this could be brought about have been proposed (reviewed by Purcell et al., 2007; Richardson et al., 2009), scarcity of long term data on gelatinous zooplankton numbers or blooms makes it difficult to corroborate claims of persistent increase (Condon et al., 2012, 2013; Sanz-Martín et al., 2016).

Relatively little has been published on species distributions or abundances of gelatinous zooplankton in Northern Norway and the wider Arctic (but see Falkenhaug, 1996; Brodeur et al., 1999, 2008; Raskoff et al., 2005; Purcell et al., 2010; Manko et al., 2015; Ronowicz et al., 2015). Nevertheless, gelatinous predators can at times exert considerable predation pressure on other zooplankton in the Arctic (Swanberg and Båmstedt, 1991; Purcell et al., 2010; Majaneva et al., 2013). The Arctic and subarctic seas are under high anthropogenic pressure, including climate change, high fishing pressure and other resource exploitation, rising levels of pollutants, and introduction of alien species (Halpern et al., 2008). Several changes in the Arctic marine ecosystem as a response to climate change have been documented, such as northward range shifts of species, changes in biodiversity, and altered food web structure (Wassmann et al., 2011). Strongly fluctuating abundances of scyphozoan jellyfish, potentially related to climatic conditions, have been reported from the subarctic seas (Brodeur et al., 1999; Eriksen et al., 2012). In recent years, increased temperature associated with increased advection of warmer Atlantic water masses has brought boreal species further into the Arctic region (Dalpadado et al., 2012). In the future, primarily Atlantic boreal gelatinous predators could be able to extend their ranges northwards into the Arctic. One of the greatest impediments to documenting and understanding changes in the gelatinous fauna of the Arctic and Subarctic is the lack of reliable baseline information from which changes can be identified. Better abundance estimates of gelatinous zooplankton, as well as an improved understanding of the conditions promoting harmful blooms and the fate and local ecosystem effects of such blooms, are crucial for future management and development of mitigation measures to minimize ecosystem, aquaculture, and fisheries impact.

In autumn 2015, several sources reported observations of large amounts of gelatinous material in North Norwegian fjords, either caught when trawling for other organisms or fouling fishing gear. Also, strong and peculiar echosounder recordings from research and fishing vessels operating in the area were reported. While such events may be frequent, they are both unpredictable and ephemeral, and are seldom documented. The mass occurrences described here were also encountered unexpectedly and the conducted sampling was far from optimal, as the vessels originally had a different focus. We have combined a range of data from a variety available sources including physical samples, trawl catch data, acoustic data, as well as photo and video evidence to describe mass occurrences of gelatinous predators, resulting in a rare account of simultaneous highdensity events of both hydrozoan and ctenophoran gelatinous zooplankton from a large subarctic archipelago and fjord system in northern Norway. Only a few catches contained substantial numbers of ctenophore Beroe spp. or hydromedusa Modeeria rotunda. These species or groups of organisms as well as nonphysonect siphonophores are nearly acoustically transparent to the echosounder frequencies used during these investigations since they do not have a gas inclusion organ. Thus, the main focus of this paper is on the physonect siphonophore Nanomia cara that has a gas-inclusion both as juvenile and adult.

Based on previous accounts on mass occurrences of gelatinous zooplankton in Norway (Båmstedt et al., 1998; Fosså et al., 2003; Småge et al., 2017, reviewed in Halsband et al., 2017), we hypothesize that abundant Nanomia colonies could potentially increase mortality of farmed and wild fish in an affected region.

\section{MATERIALS AND METHODS}

Acoustic, biological, and environmental data from Lyngenfjord, Kvænangen, and the adjacent region during the period 1 October - 9 November 2015 (Figure 1) were collected by two research vessels conducting surveys in the area, as well as from local fishermen. Additional information of anecdotal character was also obtained later in the November 2015 to January 2016 period.

\section{Survey Area}

The study area is situated north-east of Tromsø, Troms County, northern Norway. It consists of a coastal archipelago and several large fjords oriented in the north-south direction, with the Lyngenfjord system being a central feature, Balsfjord and Ullsfjord located to the west, and Reisafjord and Kvænangen 

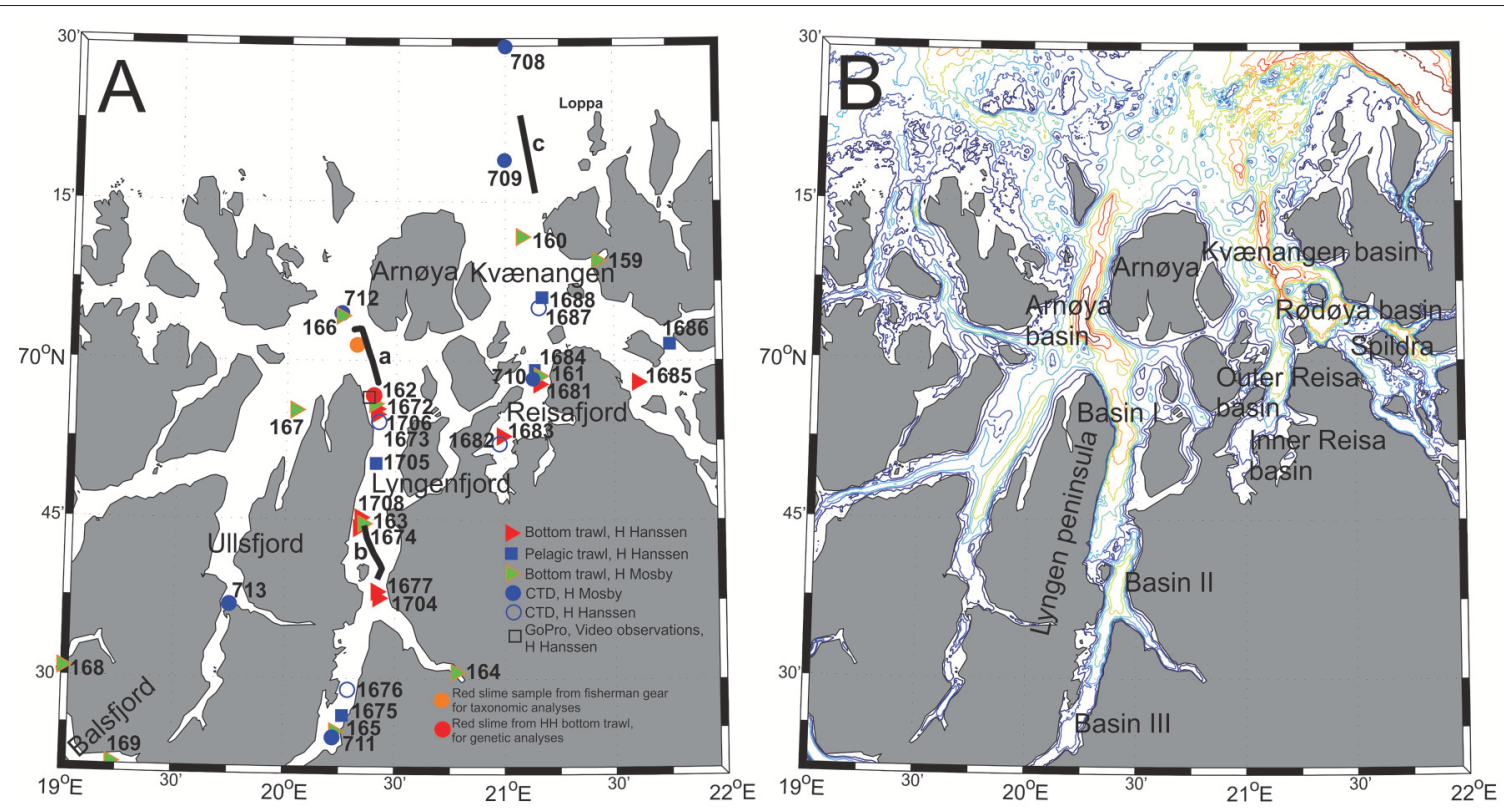

FIGURE 1 | (A) Overview of various types of sampling including trawl- and ctd-stations during the RV Håkon Mosby and RV Helmer Hanssen operations in Lyngenfjord and adjacent fjords during 6-9 October and 3-9 November 2015, respectively. a, b, and c: Acoustic transect as shown in Figures 9A-C respectively. (B) High resolution bottom topography with bottom contours, at $50 \mathrm{~m}$ intervals from 50 to $400 \mathrm{~m}$ depth. Names of deep-water basin and some other key features included.

to the east (Figures $\mathbf{1 A}, \mathbf{B})$. These coastal waters are influenced by the Norwegian coastal current (NCC) flowing in a northeasterly direction along the Norwegian coast, and by the denser and deeper Atlantic current running in parallel westwards of the coastal current. The salinity of the Atlantic water is by definition $\geq 35.0 \mathrm{psu}$, while the coastal water varies between 33 and 34.5 $\mathrm{psu}$. In general, surface water temperature in the area varies from $\sim 3^{\circ} \mathrm{C}$ in winter (March) to 10 to $12{ }^{\circ} \mathrm{C}$ in July/August. Thus, ice free conditions are maintained throughout the year in the outer coastal waters of Northern Norway, except for the innermost parts of some fjords (Aure, 1983).

The topography of the study area is complex (Figure 1B). The area seawards of the fjords is characterized by several small banks, deep depressions, and narrow channels connecting to the inner fjord systems. On either side of Arnøya, deep channels connect Lyngenfjord and Kvænangen to the open waters offshore. The particularly deep Arnøya basin (max. $\sim 450 \mathrm{~m}$ ) lies between the tip of the Lyngen peninsula and Arnøya. The Lyngenfjord consists of four basins separated by local sills (Kvendbø Hegstad, 2014). The northern basin (Basin I, max. $\sim 340 \mathrm{~m}$ ) has a $\sim 200$ $300 \mathrm{~m}$ deep outer sill located just east of the tip of the Lyngen peninsula (Jenssen, 2006). The $\sim 50-100 \mathrm{~m}$ deep sill between Basins I and II is located slightly south of $69^{\circ} 45^{\prime} \mathrm{N}$, with the shallowest areas only $\sim 20 \mathrm{~m}$ deep (Jenssen, 2006; Kvendbø Hegstad, 2014). Another $\sim 80 \mathrm{~m}$ deep sill at around $69^{\circ} 30^{\prime} \mathrm{N}$ separates Basins II and III (max. $\sim 125 \mathrm{~m}$ ), while Basin IV lies south of the map border in Figure 1.

The outer basin of Reisafjord (max. $\sim 280 \mathrm{~m}$ ) has a deep sill (200-250 m) toward the Kvænangen basin in the north. Further into the fjord, the basin becomes gradually shallower, with a $\sim 60 \mathrm{~m}$ deep sill separating the inner basin (max. $\sim 115 \mathrm{~m}$ ).
In the Kvænangen basin, maximum bottom depths are $\sim 400$ $450 \mathrm{~m}$. The deep area extends south and east of Rødøya, with maximum depths around $325 \mathrm{~m}$. Toward the south, close to the island Spildra, a cross fjord sill of $\sim 160 \mathrm{~m}$ depth (Larsen, 1997) separates the outer basin from two mid-fjord basins on either side of the island, the northern and southern basins having maximum depths of $\sim 315$ and $\sim 205 \mathrm{~m}$, respectively. Further into the fjord bottom depths become shallower with smaller local basins (Larsen, 1997).

\section{Local Fishermen Observations}

During autumn 2015, local fishermen at Arnøya reported on a particular red "slime" that stuck tenaciously to fishing gear (Figure 2). This slime was reported to contain a substantial amount of fat and threads/filaments, and was difficult to wash or mechanically remove from gear.

One sample of fouling red "slime" was obtained on 23 October 2015 by a fisherman from Arnøya who scraped it off a contaminated rope (Figure 2) that anchored a fishing net to the bottom at $\sim 275 \mathrm{~m}$ depth mid-fjord between Arnøya and the tip of the Lyngen peninsula (Figure 1). The sample was immediately fixed in $4 \%$ formalin that was prepared and made available by Gunnar Sætra (Public relations and communications Department, IMR, Tromsø) on a visit to Arnøya. It was immediately sent to Bergen for taxonomic analysis (see below). Pneumatophore gas inclusions were measured from this sample.

\section{Biological Data From Research Vessels}

Samples of fish, micronekton, and macrozooplankton were collected with a Campelen 1800 bottom trawl (Engås, 1994) by RV Håkon Mosby (2-11 October 2015) and RV Helmer Hanssen 
(3-7 November 2015). The latter vessel also used the pelagic Harstad trawl (Nedreaas and Smedstad, 1987; Godø et al., 1993) to obtain information on acoustic scattering structures.

During 2-11 October 2015, RV Håkon Mosby covered the north Norwegian fjords from Varangerfjord in the north-east to Andøya in the south-west as part of the annual IMR Coastal Survey, but only worked in the Lyngenfjord-Kvænangen area (Figure 1) on 7-9 October. In the extended area, a total of 42 bottom trawl stations were conducted (Mehl et al., 2015, St137-St178, their Figure 2), including the stations in Table $\mathbf{1 .}$ During the registration of bottom trawl catches, all types of large scyphomedusae (i.e., Cyanea, Periphylla, Aurelia) where pooled and registered as "Jellyfish".

RV Helmer Hanssen visited several fjords in the LyngenKvænangen area during 3-9 November 2015 to conduct pelagic and bottom trawl sampling, along with acoustic surveying using the Simrad EK60 echosounder system. RV Helmer Hanssen conducted nine bottom trawl hauls within the fjord system (Figure 1, Table 2). Six of the hauls were taken in Lyngenfjord and two in Reisafjord, while the last haul was taken in the inner

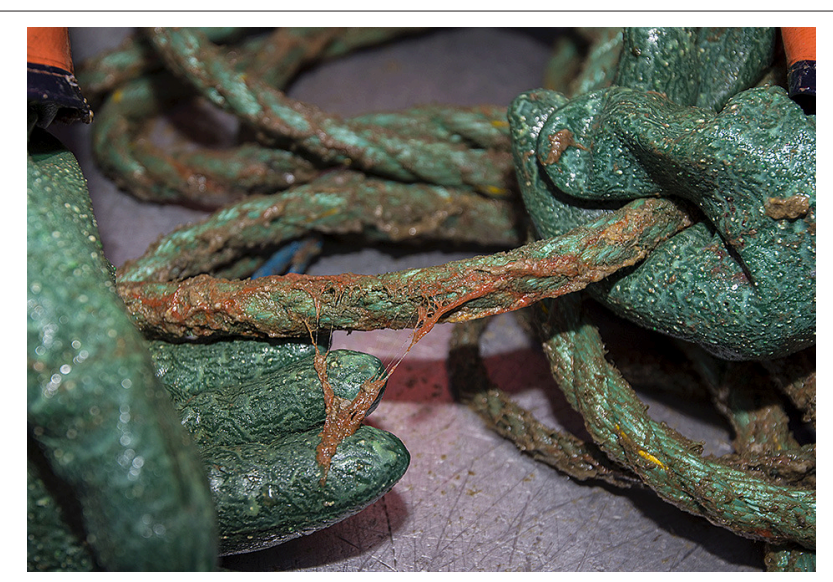

FIGURE 2 | A net rope heavily contaminated with the red "slime" documented by a fisherman from Arnøya, northern Norway. See Figure 1 for location of retrieved net. Picture taken Friday 23 October 2015. Photo: Gunnar Sætra, Institute of Marine Research, Bergen/Tromsø, Norway. part of Kvænangen. In addition, five pelagic hauls were taken in the deeper part of the water column; three of them close to the bottom and two at intermediate depths (Figure 1, Table 2).

An overview of trawl- and ctd-stations undertaken by both research vessels, along with information on acoustic transects and specific biological material collected in the target area, is provided in Figure 1, and Tables 1, 2.

Contamination of the bottom trawl (Figure 3), and catches consisting of large amounts of ctenophores and other jellies were photographically documented, particularly from RV Helmer Hanssen in Lyngenfjord and Kvænangen, 3-7 November 2015. On 9 November 2015 (at $69^{\circ} 56^{\prime} \mathrm{N} ; 20^{\circ} 23^{\prime} \mathrm{E}$ ), two vertical deployments were conducted from RV Helmer Hanssen with a double set of underwater HD GoPro video cameras mounted on a frame attached to the CTD. The cameras were kept recording in the densest part of the acoustic registrations at $30-15 \mathrm{~m}$ above the bottom for $\sim 20 \mathrm{~min}$ in Lyngenfjord, Basin I (see Figure 1), coinciding with a very strong acoustic backscatter on the echosounders registered 2 days earlier.

A second sample of the fouling red "slime" was collected from the net of a bottom trawl haul in $325 \mathrm{~m}$ water depth conducted from the RV Helmer Hanssen on 7 November 2015 just east of the northern tip of the Lyngen peninsula $\left(69^{\circ} 55.2^{\prime} \mathrm{N} ; 20^{\circ}\right.$ $24.6^{\prime} \mathrm{E}$, Figure 1). The sample was immediately frozen at $-20^{\circ} \mathrm{C}$ and later brought to the Institute of Marine Research (IMR) plankton laboratory, where a thawed subsample was examined with a stereomicroscope and several physonect colonies were separated from it and individually fixated in 95\% alcohol for genetic analyses.

\section{Hydrographic and Topographic Data}

Temperature and salinity were measured at all stations using a Seabird 911plus CTD. The CTD on RV Helmer Hanssen was equipped with a Seapoint sensor for measuring chl $a$ fluorescence, and the one on RV Håkon Mosby had a Chelsea Instrument Aquatracka III chl $a$ fluorometer. Both ship CTDs were equipped with a SBE 43 oxygen sensor.

High resolution coastal bathymetric data (originally $50 \times$ $50 \mathrm{~m}$ horizontal resolution) were obtained from the Norwegian Mapping Authority (the Norwegian Hydrographic Service) and

TABLE 1 | Overview of bottom trawl catches (kg.nmi ${ }^{-1}$ ) in Lyngen and adjacent fjords, conducted by RV Håkon Mosby within the region of Figure 1, 7-9 October 2015.

\begin{tabular}{|c|c|c|c|c|c|c|c|c|c|c|c|}
\hline \multirow[b]{2}{*}{ Date } & \multicolumn{2}{|c|}{ BALSFJORD } & \multirow[b]{2}{*}{ 9-Oct } & \multicolumn{4}{|c|}{ ULLSFJORD-LYNGENFJORD } & \multirow[b]{2}{*}{ 8-Oct } & \multicolumn{3}{|c|}{ KVAENANGEN-REISAFJORD } \\
\hline & 9-Oct & 9-Oct & & 9-Oct & 8-Oct & 8-Oct & 8-Oct & & 7-Oct & 7-Oct & 8-Oct \\
\hline Time (UTC) & $19: 45$ & $17: 27$ & $07: 38$ & $02: 32$ & $12: 03$ & $14: 32$ & 18:35 & $21: 47$ & $22: 21$ & $20: 02$ & $06: 36$ \\
\hline Station & $169^{\star \star}$ & $168^{\star \star}$ & $167^{\star}$ & 166 & 162 & 163 & 164 & 165 & 160 & 159 & 161 \\
\hline \multicolumn{12}{|c|}{ SPECIES/GROUP } \\
\hline SHRIMPS & 20.00 & 2.22 & & & 24.29 & 40.00 & & & 21.33 & & \\
\hline $\mathrm{FISH}$ & 65.29 & 107.96 & 56.47 & 5.84 & 54.89 & $1,321.39$ & 237.99 & 202.51 & 50.97 & 137.06 & 145.67 \\
\hline JELLYFISH & & 1.67 & & 41.67 & & & & & & 13.18 & 77.78 \\
\hline Trawl depth [m] & $165-177 \mathrm{~m}$ & $116-124 m$ & 255-262 m & $425-450 m$ & $325-330 \mathrm{~m}$ & 198-202 m & $81-95 m$ & $118-128 m$ & $370-400 \mathrm{~m}$ & $88-90$ m & $277-282 m$ \\
\hline
\end{tabular}

* Outer Ullsfjord. " Balsfjord, south-west of Ullsfjord. 


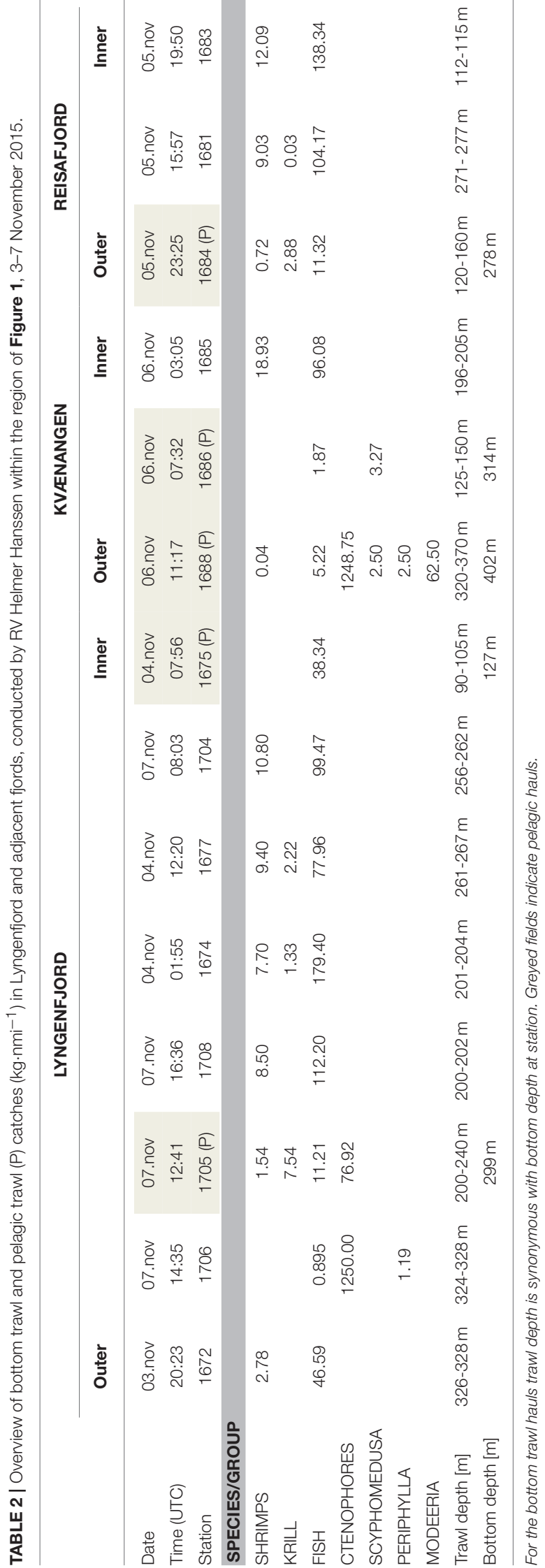

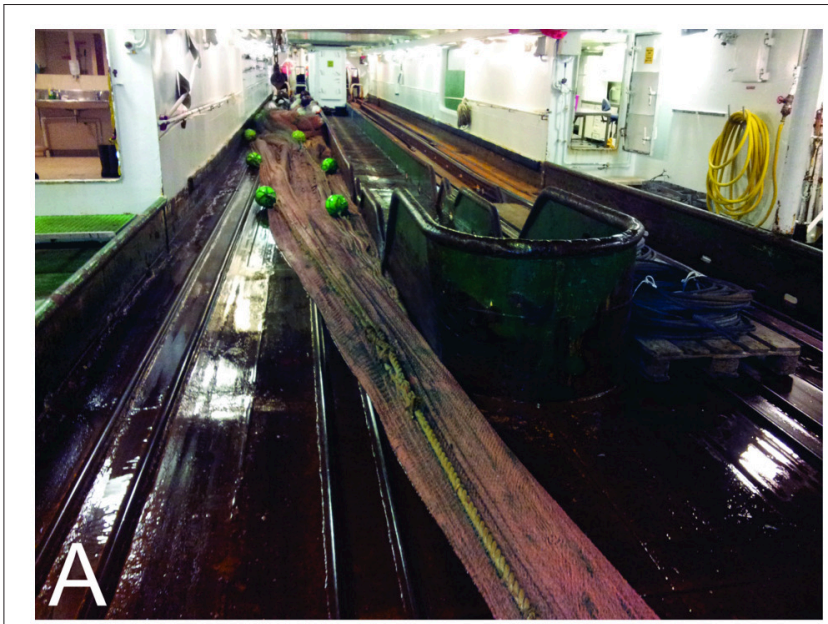

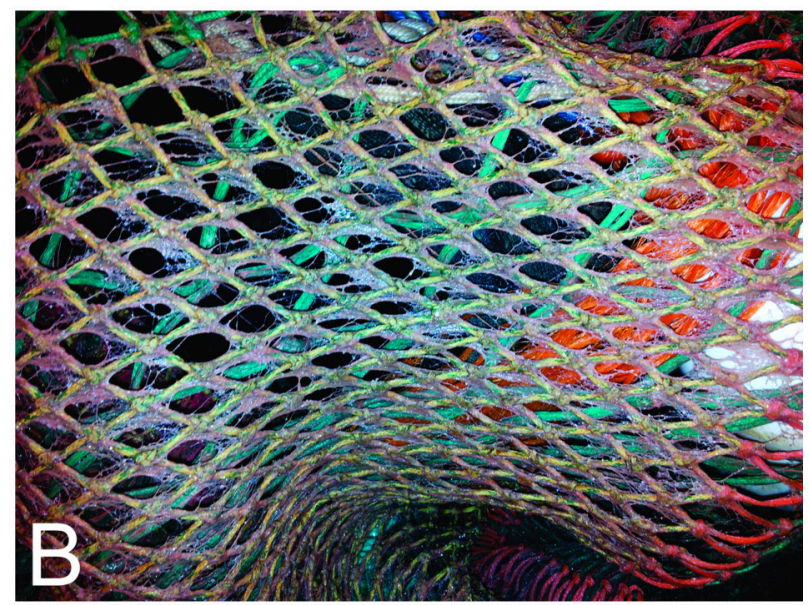

FIGURE 3 | (A) Trawl bag of RV Helmer Hanssen showing the red slime contaminating the trawl bag and (B) Close-up view of the trawl meshes, following one of the Campelen 1800\# bottom trawl hauls, st1708 on 7 November 2015 (Table 2).

the maps were produced using Matlab R2013a and M_Map version $1.4 \mathrm{~d}$.

The hydrographic data have been visualized using Ocean Data View (ODV), Schlitzer (2015) http://odv.awi.de, including section bottom topography using the IBCAO_V3_90x30sec.nc database with a $500 \times 500 \mathrm{~m}$ grid resolution (see Jakobsson et al., 2012). The fjords in the study region are up to $\sim 10 \mathrm{~km}$ wide at their mouth, but winding and narrowing toward the head of the fjords. Although the database has a reasonably high resolution, there are a restricted number of points across the width of the fjords. Depending on the way a section is selected, the number of hydrographic stations included, the width of the selected section, how the grid points within the selected region are processed by ODV, and whether they were close to a steep slope or even land grid points, the resulting bottom topography of a section could vary somewhat and was not easily reproducible. However, despite such limitations, there was a reasonable match between the contoured high-resolution topography data used in the maps (Figure 1B) and the bottom topography 
displayed through the hydrographic transects (Hydrography section below). Nevertheless, the complex bottom topography could influence the gridding and interpolation of section isosurfaces, particularly when the number of stations was low.

\section{Acoustic Data Collection}

Acoustic data for estimation of the distribution and abundance of water column plankton and fish were collected with calibrated EK60 echo sounder split beam systems at $1 \mathrm{~ms}$ pulse duration. The acoustic frequencies were 18, 38, and $120 \mathrm{kHz}$ on RV Helmer Hanssen and 18, 38, 120, and $200 \mathrm{kHz}$ on RV Håkon Mosby. On both ships, the echo sounders were connected to transducers mounted on a protruding instrument keel, with transducer faces $\sim 3 \mathrm{~m}$ below the hull and usually $\sim 8.5 \mathrm{~m}$ below the sea surface on RV Helmer Hanssen and $\sim 2.5$ and $\sim 7.5 \mathrm{~m}$ on RV Håkon Mosby. The threshold in terms of volume backscattering strength $\left(\mathrm{S}_{\mathrm{V}}\right)$ was set to $-82 \mathrm{~dB}$ re $1 \mathrm{~m}^{-1}$ (MacLennan et al., 2002). The vessels' EK60 systems are normally calibrated once a year using standard methods and metal spheres (Foote et al., 1987; ICES, 2015a) and are known to be very stable over time (Knudsen, 2009).

Echogram categorization (sometimes called scrutinization or interpretation) is based on the shape of the echo-traces, their scattering strength, and the relative frequency response $r(f)$ of scattering layers, schools, or mixed scatterings structures. The relative frequency response is defined according to Korneliussen and Ona (2003) as $\mathrm{r}(\mathrm{f}) \equiv \mathrm{s}_{\mathrm{V}}(\mathrm{f}) / \mathrm{s}_{\mathrm{V}}(38 \mathrm{kHz})$, where $\mathrm{s}_{\mathrm{V}}$ is the volume-backscattering coefficient and the response at the acoustic frequency $\mathrm{f}$ is normalized to that at $38 \mathrm{kHz}$. Echogram scrutinizing is normally carried out by an experienced team of two persons, with data available on historical catches from the waters, e.g., from previous scientific surveys, and knowledge on the behavior, abundance, and distribution of the species commonly found in the investigated area or nearby waters. Multi-frequency scrutinizing, target strength, TS, analysis and thresholding were conducted with the Large Scale Survey System (LSSS), a data post processing system (Korneliussen et al., 2006, 2016), which was also used for exporting files for subsequent analysis in Matlab and Excel. The processing involved manual removal of unwanted acoustic temporal noise from the trawl sensors during trawl operations. During the current investigations, the nature and distribution of what can be called "resonant" scattering structures, particularly at 18 and $38 \mathrm{kHz}$, were very characteristic and strong, which facilitated the "isolation" of the dominant scatterers where they occurred. Trawl data were used to corroborate the interpretation of the acoustic data. The acoustic backscattering data in the reports were in the form of $s_{A}$, the nautical area scattering coefficient (NASC) for $10 \mathrm{~m}$ depth intervals with a horizontal resolution of 1 nautical mile, in units of $\mathrm{m}^{2} \cdot \mathrm{nmi}^{-2}$ (MacLennan et al., 2002).

The multi-frequency recordings were interpreted and stored daily, mainly at $38 \mathrm{kHz}$, since the observation range of the 120 and $200 \mathrm{kHz}$ systems usually are limited to $\sim 220 \mathrm{~m}$. However, for the $120 \mathrm{kHz}$ system under calm sea state conditions and low vessel speed together with very low level of internal electronic noise, the signal to noise ratio was still acceptable to about $350 \mathrm{~m}$ depth. Interpretations were made according to standard IMR procedures (see ICES, 2015b; Korneliussen et al., 2016). First, LSSS was used to allocate backscatter to the scattering categories named "0-group herring," "Herring," "Saithe," "Haddock," "Cod," and "Others," which were later lumped in the category "Fish." The remaining backscatter was assigned to the bulk category "Plankton," which also included the "resonant" and initially unexplained scattering structures mentioned above. Only the category "Plankton" has been processed and visualized in the current work, except for example echograms showing the characteristics of the raw acoustic data.

A sub-set of the acoustic data was recorded during evening/nighttime conditions on 7 November 2015 over a $\sim 3.5 \mathrm{nmi}$ distance east of Lyngen with very dense acoustic registrations. Here, total echo integrator values, $\mathrm{s}_{\mathrm{A}}$, were stored at all three frequencies $(18,38$, and $120 \mathrm{kHz}$, RV Helmer Hanssen) with $10-\mathrm{m}$ vertical and $0.1 \mathrm{nmi}$ horizontal resolution. This allowed the examination of the frequency dependence of the $\mathrm{s}_{\mathrm{A}}$ independent of the LSSS. The ratio, $\operatorname{RFR}(\mathrm{f})$, of $\mathrm{s}_{\mathrm{A}}$ at a given frequency $\mathrm{f}$ and at $38 \mathrm{kHz}$, could then be explored as suggested by Korneliussen and Ona (2003), but here used as expressed by Godø et al. (2009): RFR(f) $=s_{A}(f) / s_{A}(38 \mathrm{kHz})$. This entails that $\mathrm{RFR}_{18}=\mathrm{s}_{\mathrm{A}}(18 \mathrm{kHz}) / \mathrm{s}_{\mathrm{A}}(38 \mathrm{kHz})$ and $\mathrm{RFR}_{120}=\mathrm{s}_{\mathrm{A}}(120 \mathrm{kHz}) / \mathrm{s}_{\mathrm{A}}$ $(38 \mathrm{kHz})$.

For this sub-set of data, it was hypothesized that siphonophores were the dominant scatterers throughout the water column. Using acoustic backscattering models, this data-set has been used to explore the likelihood that siphonophores were the key scatterers responsible for the backscattering observed throughout the water column at this particular time and also over the period of these investigations, particularly in the deeper parts of the water column.

Two backscattering models were employed to theoretically examine the effects of size and depth distribution of siphonophore gas-inclusions on the target strength (TS) and resonance frequency $\left(f_{r}\right)$, to aid the interpretation of the measured backscattering at the three used frequencies. Both models assume spherical gas-inclusions. The first, a hybrid scattering model for a fluid-filled sphere adapted for siphonophore pneumatophores (cf. Lavery et al., 2007 - see equations 3 and 4 page 3309), is a simple model that includes damping with damping constant, $\delta$, for $k a<0.1$, where $k a$ is the product of wavenumber $(k)$ and $(a)$ is the bubble radius of the modeled siphonophore gas bubble. A shortcoming of this hybrid model is that the quality factor, $\mathrm{Q}=\delta^{-1}$, is seemingly too small $(=5)$, which yields $\delta=0.2$ (cf. Lavery et al., 2007), but was originally proposed by Diachok (2001) as typical for swim-bladdered fish. However, for resonant and near-resonant oscillating bubbles in water this number is not possible to achieve at any frequency (Dalen and Løvik, 1981; Medwin and Clay, 1998, p. 301), but for comparative purposes we have kept the value proposed by Diachok (2001) and implemented in Lavery et al. (2007).

The second model is the exact modal series solution, originally for a fluid sphere (Anderson, 1950). To examine the difference between the exact model and the hybrid damped model, both models were applied to a broad frequency range and a restricted set of gas bubble sizes, $a=0.20,0.30$ for depths $17.5,50$, and $100 \mathrm{~m}$ and $a=0.45,0.50$, and $0.55 \mathrm{~mm}$ for depths 0,100 , and $300 \mathrm{~m}$, also for $k a>0.1$. For the frequencies 18 and $38 \mathrm{kHz}, k a$ is $<0.1$ for any sized gas bubble having a radius $(a)$ in the range 
$0.1 \leq a \leq 0.55 \mathrm{~mm}$. For a $0.5 \mathrm{~mm}$ radius sphere at $0 \mathrm{~m}$ and $300 \mathrm{~m}$ depth $\mathrm{ka}$ is $\approx 0.25$ at $120 \mathrm{kHz}$, but the two models still produce very similar values (Supplementary Figure S1).

In this study, the pneumatophore gas bubble "size" is given by the Equivalent Spherical Radius (ESR) of a sphere of the same volume as a prolate ellipsoid with major and minor axes given by the measured length (L) and width (W), ESR $=\left[\left(L W^{2}\right)^{1 / 3}\right] / 2$. The same applies for the average values of gas bubble length and width obtained from Barham (1963).

To understand how the target strength, TS, of a siphonophore gas-inclusion varies with size and depth, the hybrid scattering model (Lavery et al., 2007) was run for spheres in the size range $0.10 \leq a \leq 1.01 \mathrm{~mm}$ with $0.05 \mathrm{~mm}$ steps, considering 5 -m depth strata from $20-335 \mathrm{~m}$ depth. A variable sound velocity profile obtained at st 1673 on 3 November 2015 was applied (i.e. the same location as the acoustic data from 7 November). High resolution sound velocity data (range $1479.00-1485.55 \mathrm{~m} \cdot \mathrm{s}^{-1}$ ) from the Seabird Scientific's SBE 911plus CTD were averaged over a restricted number of records $(N=9-15)$, surrounding the 5-m depth strata for which the hybrid dampened acoustic scattering model was run.

The vertical distribution of target strength at 18,38 , and $120 \mathrm{kHz}$ for three different sizes of siphonophore gas-inclusions ( $\mathrm{a}=0.45,0.50$, and $0.55 \mathrm{~mm}$ ESR) were derived from the hybrid model, $\mathrm{TS}_{\mathrm{Hyb}}$. These were used along with the stratified nautical area scattering coefficients data for the corresponding frequencies $\left(\mathrm{s}_{\mathrm{A}}-\mathrm{m}^{2} \cdot \mathrm{nmi}^{-2}, 10-\mathrm{m}\right.$ depth bins vertically and 0.1 nmi distance horizontally), to compute and explore the area and volume density of siphonophores /gas-filled pneumatophores in the water column applying the following equations;

$$
\begin{aligned}
\sigma_{b s} & =10^{\left(0.1 \cdot \mathrm{TS}_{\mathrm{Hyb}}\right)}, \\
\mathrm{A} 1 & =\frac{\mathrm{s}_{\mathrm{A}}}{\left(4 \cdot \pi \cdot \sigma_{\mathrm{bs}}\right)}, \\
\mathrm{A} 2 & =\frac{\mathrm{A} 1}{1852^{2}}, \\
\mathrm{~V}_{\text {Dens }} & =\frac{\mathrm{A} 2}{\Delta \mathrm{z}},
\end{aligned}
$$

Here $\sigma_{b s}$ is the backscattering cross-section $\left(\mathrm{m}^{2}\right), \mathrm{TS}_{\mathrm{Hyb}}$ is the depth specific target strength from the hybrid scattering model in $\mathrm{dB}$ re $1 \mathrm{~m}^{2}$, used according to MacLennan et al. (2002) while applying the echo sounder system, EK60, from Kongsberg Maritime AS for data acquisition. A1 equals number of gas-inclusion per square nautical miles $\left(\mathrm{Nos} / \mathrm{nmi}^{2}\right)$, A2 equals number of gas-inclusion per square meter $\left(\mathrm{Nos} / \mathrm{m}^{2}\right), \mathrm{V}_{\text {Dens }}$ equals volume density $\left(\mathrm{Nos} / \mathrm{m}^{3}\right)$, and $\Delta \mathrm{z}$ is the depth interval $(10 \mathrm{~m})$ for which the $\mathrm{s}_{\mathrm{A}}$ were computed from the raw acoustic data on 7 November 2015 (see above).

Generally, maximum backscattering from an ensemble of bubbles (here siphonophores), is obtained when the bubbles are ensonified with frequencies that make them oscillate at their resonance or near-resonance frequencies (Medwin and Clay, 1998, 287-341). Even if there is no coincidence or match between the applied frequencies and resonant bubbles, still considerable amounts of backscattered intensity can be expected-i.e., from smaller bubbles below their resonance region in the Rayleigh scattering zone, and from larger bubbles above their resonance region in the geometric scattering zone. For this reason, also smaller gas-bubble sizes were explored with respect to target strength, and resonance at the above frequencies.

\section{Genetic Analyses}

To confirm the species identity of the physonect siphonophores, $16 \mathrm{~S}$ and Cytochrome oxidase I (COI) markers were sequenced from seven colonies separated from a sample of slime fouling a trawl net on RV Helmer Hanssen on 7 November 2015. The DNA was isolated using DNeasy blood and tissue kit, according to the protocol supplied by the manufacturer (Qiagen). PCR was used to amplify fragments of the $16 \mathrm{~S}$ and COI.

The 16S fragment was amplified using primers primer 1/primer 2 (Cunningham and Buss, 1993). The PCR profile was 10 cycles of $94^{\circ} \mathrm{C}, 60 \mathrm{~s} ; 40^{\circ} \mathrm{C}, 30 \mathrm{~s} ; 72^{\circ} \mathrm{C}, 150 \mathrm{~s}$, followed by 40 cycles of $94^{\circ} \mathrm{C}, 60 \mathrm{~s} ; 52^{\circ} \mathrm{C}, 30 \mathrm{~s} ; 72^{\circ} \mathrm{C}, 150 \mathrm{~s}$. Amplification was verified by gel electrophoresis showing a single band of expected size (app. $650 \mathrm{bp}$ ). The COI fragment was amplified using primers LCO-1490/ HCO-2607 (Folmer et al., 1994; Bucklin et al., 2010). Amplification was verified by gel electrophoresis showing a single band of expected size (app. $1100 \mathrm{bp}$ ). The PCR profile was $94^{\circ} \mathrm{C}$, $300 \mathrm{~s}$, proceeded by 40 cycles of $94^{\circ} \mathrm{C}, 60 \mathrm{~s} ; 45^{\circ} \mathrm{C}, 120 \mathrm{~s} ; 72^{\circ} \mathrm{C}$, $180 \mathrm{~s}$. For both markers, amplicons were subsequently sequenced by Sanger sequencing using BigDye and the above primers.

The obtained COI and 16S sequences were aligned using Muscle (default settings) in MEGA 7.0.18. Trimmed sequences were compared pairwise (with complete deletion of gaps) for nucleotide differences and percentage similarity in MEGA 7 and matched against nucleotide sequences present in GenBank using NCBI BLASTn 2.5.1 (Zhang et al., 2000) to confirm their identity.

\section{RESULTS}

\section{Hydrography}

CTD stations were undertaken in Lyngenfjord and Kvænangen during the course of the two cruises with RV Håkon Mosby (October) and RV Helmer Hanssen (November). To evaluate the oceanographic conditions during the surveys, the ctd-data from the two vessels, obtained 1 month apart, have been combined in the same graph (Figure 4). The highly saline Atlantic Water (AW, salinity $\geq 35.00 \mathrm{psu}$ ) was present only in the deeper part of the water column in the coastal waters outside the fjord system (Figure 4A). The Arnøya basin from $\sim 100-450 \mathrm{~m}$ depth appears to contain water of primarily coastal origin (salinities $<34.80$ $\mathrm{psu}$ ). This water also extended into the outer part of Lyngenfjord Basin I, but not further into the fjord. In Lyngenfjord Basins II and III salinity was around 33.78-33.84 psu in waters below $100 \mathrm{~m}$, but lower in the surface layers due to freshwater runoff. This fresher surface layer extended seawards into Basin I. The salinity distribution (Figure 4A) shows no indication of Atlantic Water ( $\geq 35.00 \mathrm{psu}$ ) being introduced to the fjord systems during the period of these investigations.

Temperature in the Arnøya basin and in Basin I was mostly below $7.5^{\circ} \mathrm{C}$ at depths $>150 \mathrm{~m}$ (Figure 4B). Surface water temperatures in the Arnøya basin and coastal area $\left(9-10^{\circ} \mathrm{C}\right)$ were somewhat higher than in Basin $\mathrm{I}\left(<8^{\circ} \mathrm{C}\right)$, but this may represent seasonal cooling of the upper water column, as the 


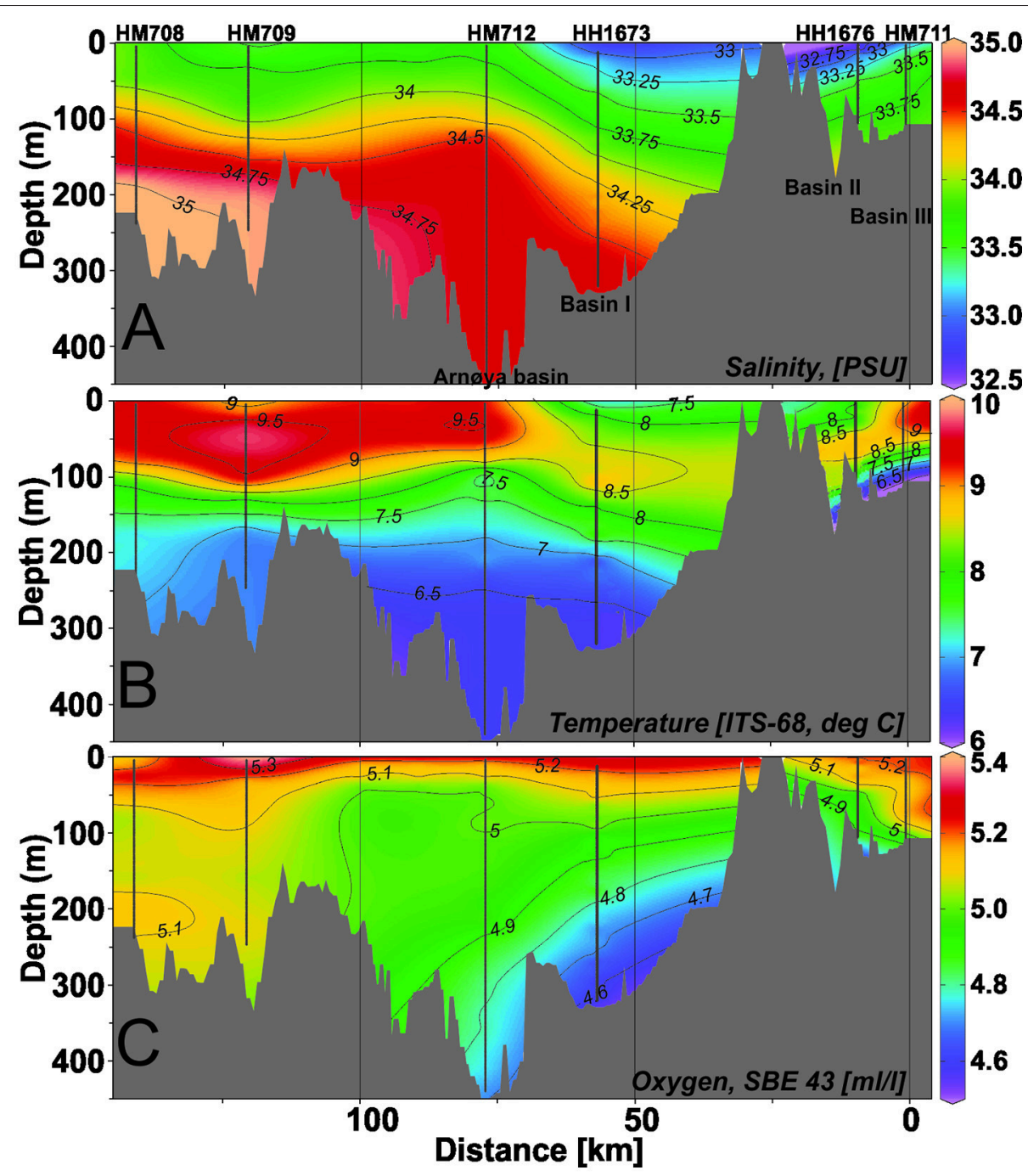

FIGURE 4 | Hydrographic conditions along a transect from the outer coastal areas in the north (left), the Arnøya basin (center) and Lyngenfjord basins in the south (right), during October-November 2015. Research vessel ctd-station numbers on top of the figure with prefix HM (RV Håkon Mosby) and HH (RV Helmer Hanssen), respectively. (A) Salinity (psu), (B) Temperature $\left({ }^{\circ} \mathrm{C}\right)$, (C) Oxygen $\left(\mathrm{ml} \cdot \mathrm{I}^{-1}\right)$.

former temperatures were recorded in October and the latter in November.

Oxygen levels in Lyngenfjord were moderate to low (4.6$5.5 \mathrm{ml} \cdot \mathrm{l}^{-1}$ ) throughout the water column (Figure 4C). Lowest oxygen concentrations were observed in the Arnøya basin, where the $\mathrm{O}_{2}$ concentration in early October was below $4.9 \mathrm{ml} \cdot \mathrm{l}^{-1}$ from $\sim 230 \mathrm{~m}$ to the bottom, and in Lyngenfjord Basin I, where concentrations in November were below $4.9 \mathrm{ml} \cdot \mathrm{l}^{-1}$ from $\sim 130 \mathrm{~m}$ to the bottom $(\sim 325 \mathrm{~m})$. Close to bottom, oxygen concentration in the Arnøya basin was $\sim 4.72 \mathrm{ml} \cdot \mathrm{l}^{-1}$ and in Lyngenfjord Basin I $\sim 4.57 \mathrm{ml} \cdot \mathrm{l}^{-1}$. The coastal stations outside the fjord (Figure $4 \mathrm{C}$ ) had higher oxygen levels over the entire water column $(\sim 5.0-5.3$ $\left.\mathrm{ml} \cdot \mathrm{l}^{-1}\right)$.

Hydrographic conditions in Kvænangen-Reisafjord were quite similar to those in Lyngenfjord. At the central station of outer Kvænangen (HH1687), oxygen concentrations were $<5.0 \mathrm{ml} \cdot \mathrm{l}^{-1}$ below $\sim 100 \mathrm{~m}$ and ca. $4.84 \mathrm{ml} \cdot \mathrm{l}^{-1}$ close to the bottom at $\sim 350 \mathrm{~m}$ (November). In the northern basin of Reisafjord, oxygen values were slightly higher throughout the water column and only $<5.0 \mathrm{ml} \cdot \mathrm{l}^{-1}$ below $250 \mathrm{~m}$ depth (October). These values are comparable to what was reported for the Arnøya basin in October. At the innermost station in Reisafjord, oxygen values ranged from $\sim 5.3 \mathrm{ml} \cdot \mathrm{l}^{-1}$ in the surface layer to $4.86 \mathrm{ml} \cdot \mathrm{l}^{-1}$ close to the bottom at $102 \mathrm{~m}$. There were no signs of Atlantic water penetrating the outer part of Kvænangen and Reisafjord as both fjords had a bottom water salinity of around 34.60 psu.

\section{Local Fishermen Observations}

Morphological examination under a stereo-microscope of the material collected by a fisherman on 23 October 2015 suggested the "slime" was remnants of physonect siphonophores. Diagnostic structures identified in the filamentous mass included 
pneumatophores, palpons, and gastrozoids (Figure 5). While no nectophores that could aid in species identification were preserved, the presence of oil droplets, typically found at the base of palpons in Nanomia spp. (Mapstone, 2009), suggested Nanomia as a candidate genus. The pneumatophore in Figure 5 was measured in November 2015, while the remaining gasinclusions were measured 1 year later. The size range of the pneumatophore gas-inclusions $(N=11)$ in terms of ESR was $0.34-0.56 \mathrm{~mm}$. The largest gas-inclusion was the one measured and photographed in 2015, while many of the pneumatophores measured in 2016 were partly collapsed (distorted shape), with at least one ruptured pneumatophore, and obviously contained less gas than could be expected compared to the seemingly intact specimen in Figure 5.

The fishermen also observed the phenomenon on their vessels' echosounders and sometimes described it as "dense as herring schools." According to the fishermen this "slime" was located in a layer below $\sim 150 \mathrm{~m}$, with seemingly increasing density toward the bottom at $\sim 300 \mathrm{~m}$ depth. It was reported that the "slime" had increased in magnitude from around 20 August 2015, and that it had been present in the area from that date onwards, while the last reports on the fouling red "slime" were from January 2016. According to other fishermen, the phenomenon was also observed in the areas outside Lyngenfjord, in Reisafjorden and Kvænangen. Several fishermen claimed it was the first time this type of phenomenon had been observed in the area, but another described an event that took place in 1959/1960.

\section{Research Vessel Observations Biological Data From RV Håkon Mosby}

No catch that could be assigned to the category Jellyfish were caught in 30 of the total 42 bottom trawl hauls made by RV Håkon Mosby within the extended study area during the annual IMR Coastal Survey. "Jellyfish" were registered in eight of the

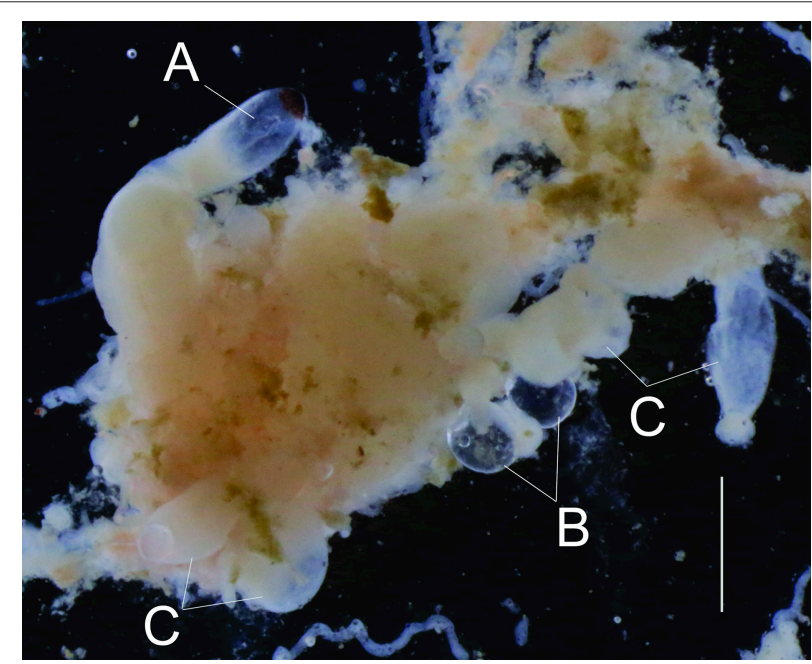

FIGURE 5 | Formalin fixated remnants of siphonophoran origin collected by a fisherman and scraped off a net rope outside Arnøya (Troms, Norway) on 23 October 2015. A, pneumatophore; B, oil droplets; C, palpons/gastrozooids. Scale bar at lower right of length $2 \mathrm{~mm}$. hauls taken outside the current target area $(N=31)$, with the average catch of jellies in these 8 hauls being $15.99 \mathrm{~kg} \cdot \mathrm{nmi}^{-1}$ $\left(\mathrm{std}=27.65 \mathrm{~kg} \cdot \mathrm{nmi}^{-1}, \max =83.0\right.$ and $\left.\min =0.67 \mathrm{~kg} \cdot \mathrm{nmi}^{-1}\right)$ and no extreme values recorded. Within the target area (Figure 1 and Table 1), "Jellyfish" were recorded in four of the 11 hauls, the average catch in these 4 hauls being $33.57 \mathrm{~kg} \cdot \mathrm{nmi}^{-1}[\mathrm{std}=33.93$ $\mathrm{kg} \cdot \mathrm{nmi}^{-1}\left(\max =77.78\right.$ and $\left.\min =1.67 \mathrm{~kg} \cdot \mathrm{nmi}^{-1}\right)$.

The mean catch of jellies in the bottom trawls within the target area (Figure 1) was not significantly different compared to the wider area covering the North Norwegian fjords north of $68^{\circ} 30^{\prime} \mathrm{N}$ (Welch two sample t.test ( $\mathrm{R}$ version 3.2.3; R Core Team, 2015), zero's not included: $t=-0.898, \mathrm{df}=5.083, p$-value $=0.4097$ and zero's included: $t=-1.0034, \mathrm{df}=12.666, p$-value $=0.3344)$. No ctenophores were registered in the trawl catches, and the jellies caught in these hauls were probably scyphozoans such as Cyanea capillata, Aurelia aurita, and Periphylla periphylla, as these large species are the most common in the fjords and in the Atlantic and coastal waters along the northern Norwegian coast.

It was reported from RV Håkon Mosby that at some stations within the study area, the bottom trawl clogged severely and required thorough cleaning between hauls due to contamination by the red "slime" mentioned earlier. This was particularly evident at st166 in the Arnøya basin, where it probably also influenced the fish catch, which was only $5.84 \mathrm{~kg} \cdot \mathrm{nmi}^{-1}$ and much lower than at the other stations (Table 1). This information to a large extent supports the reports by local fishermen of poor catches and heavy contamination of their fishing gear (cf. Figure 2). Also, the IMR Coastal Survey cruise report (Mehl et al., 2015) suggested somewhat lower catches of fish in the Lyngenfjord-Kvænangen area compared to the larger area examined during their investigations.

\section{Biological Data From RV Helmer Hanssen}

Of particular interest were two nighttime bottom trawl hauls conducted at nearby locations in the outer part of Lyngenfjord on 3 November (St1672, 326-328 m) and 7 November (St1706, $324-328 \mathrm{~m}$ ). The first haul gave a fish catch of $46.6 \mathrm{~kg} \cdot \mathrm{nmi}^{-1}$ and contained no ctenophores. In the second haul 4 days later, $1250 \mathrm{~kg} \cdot \mathrm{nmi}^{-1}$ of ctenophores and only $0.9 \mathrm{~kg} \cdot \mathrm{nmi}^{-1}$ of fish were caught (Table 2). Based on photos of the catch, the ctenophores were mostly Beroe cf. cucumis (Figure 6A).

In a daytime pelagic haul in Kvænangen (St1688, bottom depth $402 \mathrm{~m}$ ) at a sampling depth of 320-370 m, a ctenophore (Beroe cf. cucumis) catch of $1248.75 \mathrm{~kg} \cdot \mathrm{nmi}^{-1}$ was recorded on 6 November. This latter haul was the only one where numerous $M$. rotunda hydromedusae were registered (Figure 6B), the catch of this species being $62.5 \mathrm{~kg} \cdot \mathrm{nmi}^{-1}$.

During another daytime pelagic haul in Lyngenfjord (St1705, bottom depth $\sim 300 \mathrm{~m}$, Figure 1) at 200-240 m depth, 76.92 $\mathrm{kg} \cdot \mathrm{nmi}^{-1}$ of ctenophores were recorded on 7 November 2015. A total of $11.2 \mathrm{~kg} \cdot \mathrm{nmi}^{-1}$ fish were caught simultaneously, with haddock being the key species $\left(9.3 \mathrm{~kg} \cdot \mathrm{nmi}^{-1}\right)$. The catches of scyphozoan jellyfish in the bottom trawl hauls within the study region were very low in November (Table 2).

On 9 November, during a brief revisit to the area, dense acoustic backscatter was still evident on the echosounder display. The video recordings obtained on this date (Figure 1), clearly 


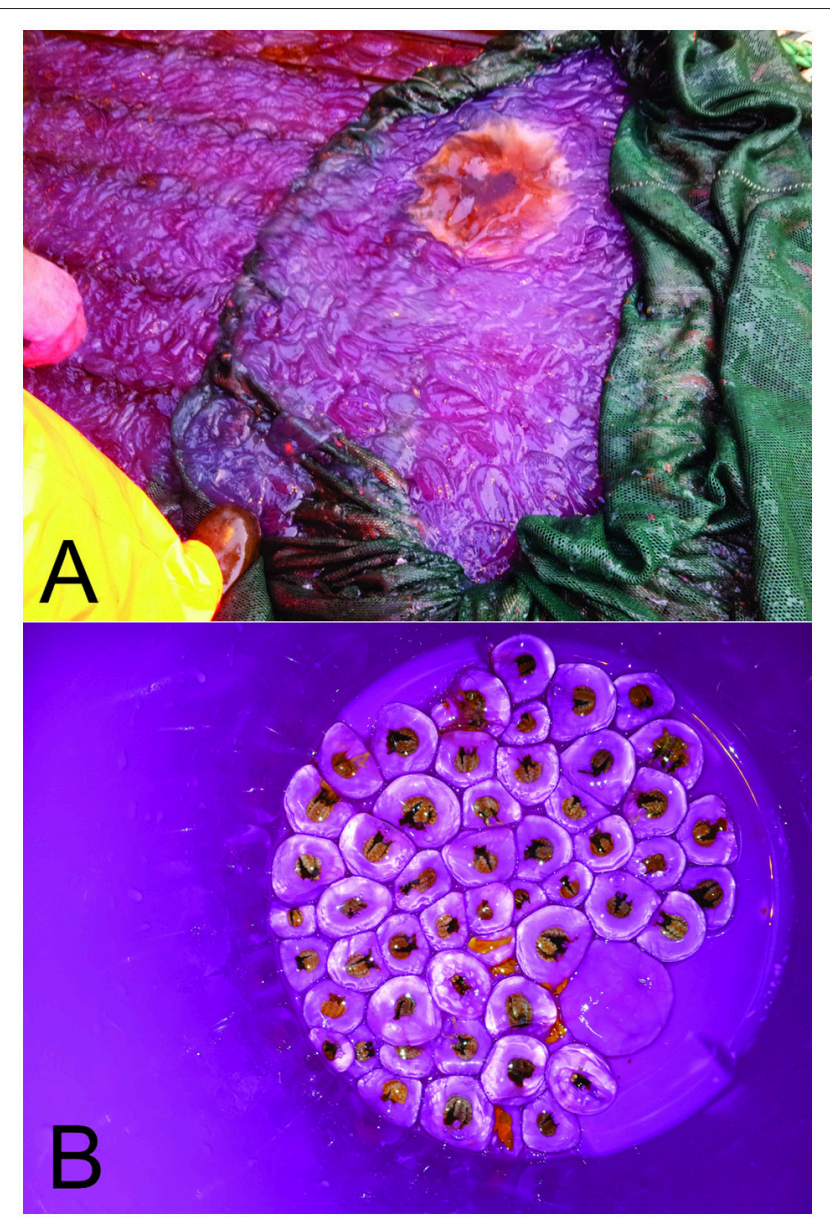

FIGURE 6 | (A) Picture showing the dominant species, the ctenophore Beroe cucumis caught by pelagic trawl st1688 on 6 November 2015. Note the boot in the lower left part of the picture as a "size reference." (B) Exemplary specimens of the hydrozoan Modeeria rotunda in the bottom of a plastic bucket ( $15 \mathrm{~cm}$ diameter) caught in the pelagic trawl st1688 on 6 November 2015 .

showed agalmid physonect siphonophores, likely Nanomia sp. (Figure 7), actively swimming around. A range of colony sizes appeared to be present, but due to the quality of the recordings, limited field of view, and organism density, neither size nor water column stratified abundances colonies were possible to estimate.

\section{Echo Sounder Registrations}

According to echosounder data from RV Håkon Mosby (69 October 2015) and RV Helmer Hanssen (3-7 November 2015), the highest concentrations of the scrutinized category "Plankton" were found on the eastern side of Lyngenfjord Basin I and in the Arnøya basin (Figures 8, 9A). Elevated levels were also evident in the outer part of Kvænangen, east of Arnøya toward the open ocean, and even in coastal waters outside the fjord (Figure 8). Echogram images from October clearly show dense registrations $\left(\mathrm{s}_{\mathrm{A}} \approx 15,000 \mathrm{~m}^{2} \cdot \mathrm{nm}^{-2}\right)$
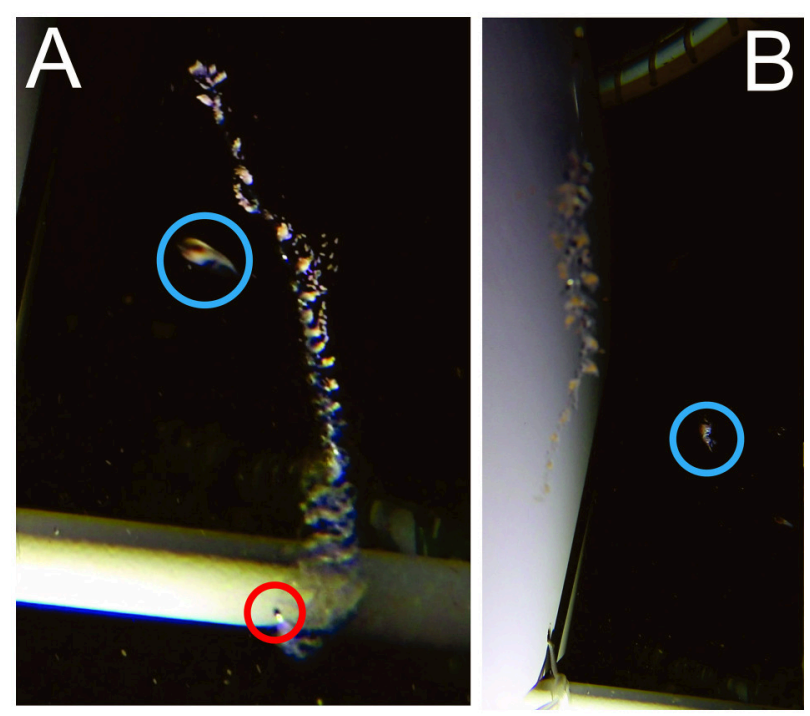

FIGURE 7 | Still photos from the GoPro video recordings at $265 \mathrm{~m}$ depth in Lyngenfjord on 9 November 2015 (cf. Figure 1), showing most probably physonect siphonopohores. (A) Specimen with pneumatophore encircled (red ring) and an amphipod (cyan ring). (B) Siphonophore with an amphipod encircled (cyan ring) to indicate size difference between the two. The amphipod could be of the genus Themisto and $\sim 2-3 \mathrm{~cm}$ in total length. Note the pinkish to orange coloration of the gastrozooids and/or gonophores. The white bar at the bottom of both images and at the top of $(\mathbf{B})$ are parts of the Seabird CTD frame. According to Seabird the distance between upper and lower part of this frame is $82.5 \mathrm{~cm}$. See http://www.seabird.com/sbe32carousel-water-sampler.

also in the deeper depressions here, west of the island Loppa (Figures 1, 9C).

The category "Plankton" showed mostly lower values in the upper part of the water column $(<150 \mathrm{~m})$, although elevated values $\left(\mathrm{S}_{\mathrm{A}}=30-32 \mathrm{~dB}\right.$ re $1\left(\mathrm{~m}^{2} \cdot \mathrm{nmi}^{-2}\right)$ were observed in regions with high values below $150 \mathrm{~m}$ depth. In the shallow inner fjords, the abundance of the category Plankton was very low both below and above $150 \mathrm{~m}$ (Figure 8). In Lyngenfjord, denser registrations were recorded along the bottom in Basin I, but did not extend into Basin II (Figures 8, 9B).

In October, RV Håkon Mosby recorded maximum $\mathrm{s}_{\mathrm{A}}$ values of $\sim 30 \quad 000 \mathrm{~m}^{2} \cdot \mathrm{nm}^{-2}$ integrated over the water column from the $38 \mathrm{kHz}$ echosounder (Mehl et al., 2015). One month later, RV Helmer Hanssen recorded integrated values of $\sim 100000 \mathrm{~m}^{2} \cdot \mathrm{nm}^{-2}$ averaged over a $1 \mathrm{nmi}$ distance (Figure 10, Log 8624-8625, 7 November 2015) just east of the northern tip of the Lyngen peninsula. These night time recordings show very dense registrations throughout the water column, increasing toward the bottom, and seemingly extending into the epipelagic more than can been seen from the RV Håkon Mosby recordings 1 month earlier (Figure 9A).

Maximum $\mathrm{s}_{\mathrm{A}}$ values recorded in November 2015 by RV Helmer Hanssen in the deeper part of the water column (bottom$-150 \mathrm{~m}$ ) were $\sim 3.5$ times higher than what was recorded with RV Håkon Mosby 1 month earlier. During both surveys, the 

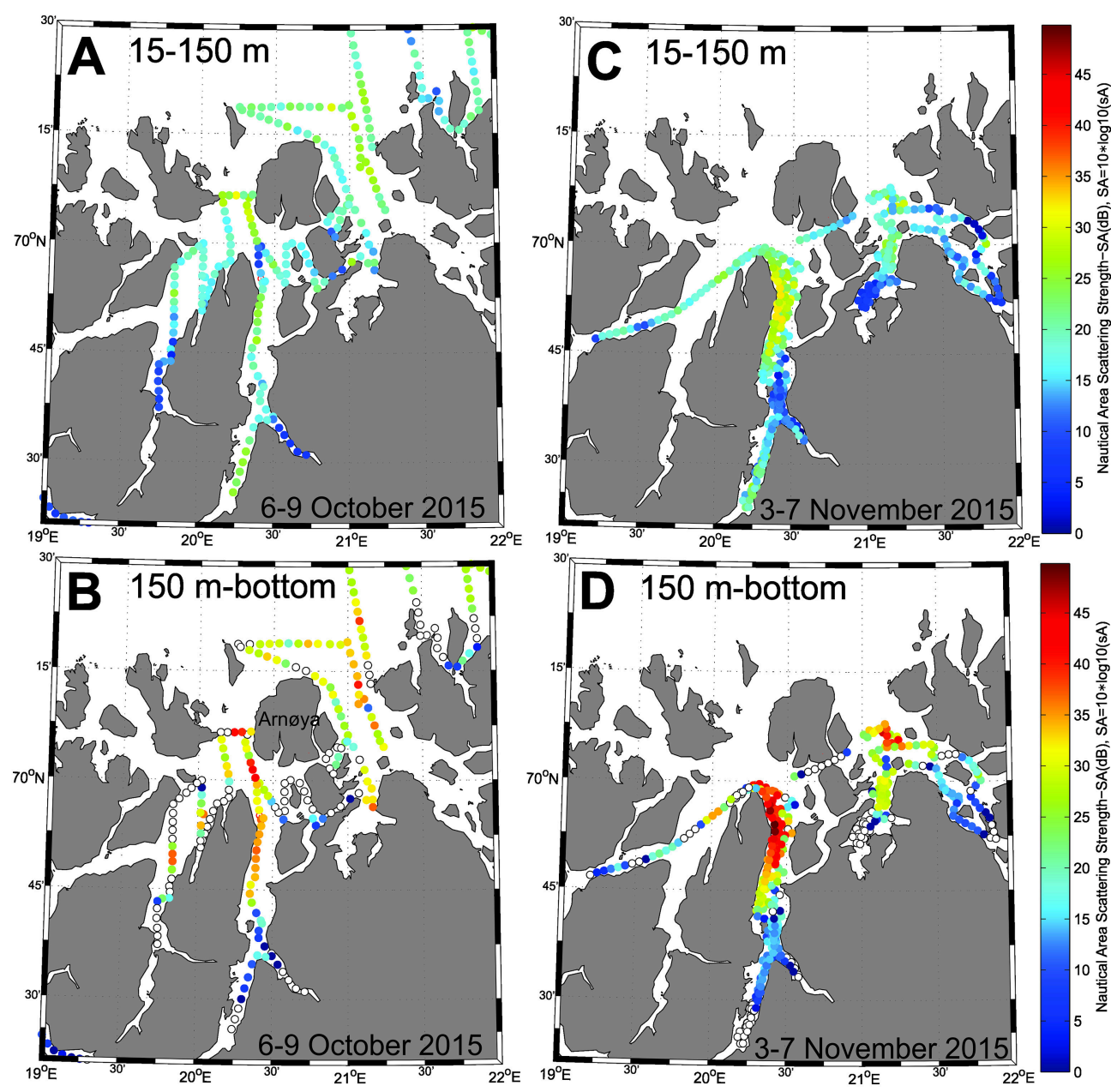

FIGURE 8 | (A,B) Acoustic registrations per 1 nmi cruise track scrutinized as Plankton, 6-9 October 2015 with RV Håkon Mosby. (C,D) Acoustic registrations per 1 nmi cruise track scrutinized as Plankton, 3-7 November 2015 with RV Helmer Hanssen. (A,C) Integrated values of $s_{A}\left(m^{2} \cdot n_{m i}{ }^{-2}\right)$ between 15 and $150 m$ depth. (B,D): Integrated values of $\mathrm{s}_{\mathrm{A}}\left(\mathrm{m}^{2} \cdot \mathrm{nmi}^{-2}\right)$ between $150 \mathrm{~m}$ and bottom. Data presented as nautical area scattering strength $\left(\mathrm{S}_{\mathrm{A}}, \mathrm{dB}\right.$ re $\left.1 \mathrm{~m}^{2} \cdot \mathrm{nmi}{ }^{-2}\right)$,

$S_{A}=10 \log _{10}\left(S_{A}\right)$. Open white circles in panel $(\mathbf{B}, \mathbf{D})$ represent locations where bottom depth is shallower than $150 \mathrm{~m}$, thus containing no acoustic data.

highest values were observed in the layer extending $150 \mathrm{~m}$ from the bottom, increasing with depth (e.g., Figures 9A-C, 10).

The vertical structure of backscattering over an acoustically reasonably homogenous distance of ca $3.5 \mathrm{nmi}$ in the deepest part of Lyngenfjord Basin I (cf. Figures 1, 10) was examined for all available frequencies; 18, 38, and $120 \mathrm{kHz}$ (Figure 11). This is to understand and quantify how the acoustic backscattering varied with depth in an area seemingly dominated by physonect siphonophores with a gas-filled pneumatophore, and to estimate the density of these organisms. In the linear domain, acoustic backscattering at $18 \mathrm{kHz}$ dominated in most of the epipelagic with average $\mathrm{s}_{\mathrm{A}}$ values in the range $350-420 \mathrm{~m}^{2} \cdot \mathrm{nmi}^{-2}$, and a secondary peak of $\sim 200 \mathrm{~m}^{2} \cdot \mathrm{nmi}^{-2}$ at $\sim 320 \mathrm{~m}$ depth. A shift in dominant frequencies occurred at $\sim 130 \mathrm{~m}$ depth, below which average $s_{A}$ for $38 \mathrm{kHz}$ was higher than for $18 \mathrm{kHz}$, reaching a peak of $\sim 22,000 \mathrm{~m}^{2} \cdot \mathrm{nmi}^{-2}$ around $320 \mathrm{~m}$ depth. The mean $\mathrm{s}_{\mathrm{A}}$ at $120 \mathrm{kHz}$ was much lower in most of the water column, $\sim 18-67$ $\mathrm{m}^{2} \cdot \mathrm{nmi}^{-2}$ in the upper $250 \mathrm{~m}$ with a peak of $\sim 1,900 \mathrm{~m}^{2} \cdot \mathrm{nmi}^{-2}$ at $\sim 325$ m depth-about an order of magnitude lower than recorded at $38 \mathrm{kHz}$. It is also observed that the trend in $\mathrm{S}_{\mathrm{A}}$ (nautical area scattering strength) vs. depth at 38 and $120 \mathrm{kHz}$ were very similar.

In terms of the Relative Frequency Response, $\mathrm{RFR}_{120}$, was close to 1 in the upper $50 \mathrm{~m}$ of the water column, thus quite similar to the backscattering at $38 \mathrm{kHz}$, while the backscattering displayed as $\mathrm{RFR}_{18}$ peaked between 45 and $65 \mathrm{~m}$ being $10-$ 12 times the backscattering at $38 \mathrm{kHz}$ here (Figure 11). It is evident that the backscattering at $38 \mathrm{kHz}$ considerably dominated over backscattering at 18 and $120 \mathrm{kHz}$ from about $150 \mathrm{~m}$ to the bottom. This indicates that there likely is resonant scattering at $38 \mathrm{kHz}$ taking place in the deeper part of the water column.

\section{Acoustic Scattering Models, Siphonophore Gas-Inclusion Target Strengths and Abundance}

Both the full modal series solution and the hybrid models demonstrate by Figure 12 that gas-filled spheres with equivalent spherical radii (ESR) of $0.20 \mathrm{~mm}$ have their resonance 


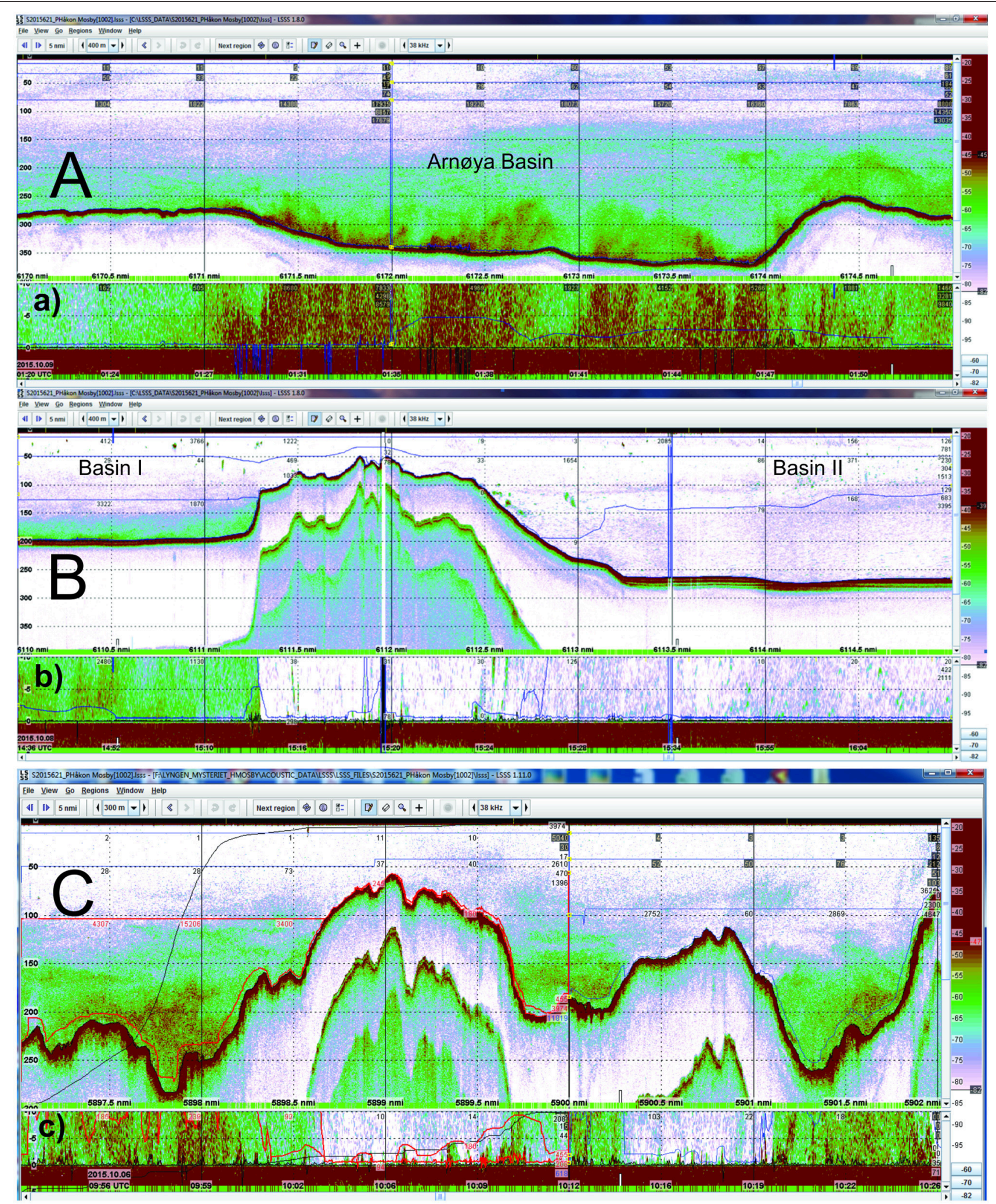

FIGURE 9 | Echograms obtained at $38 \mathrm{kHz}$ from RV Håkon Mosby in Lyngenfjord and nearby area. (A) Acoustic record between Arnøya and the tip of the Lyngen peninsula on 9 October 2015. (B) Acoustic record from the central part of Lyngenfjord crossing the sill from Basin I to Basin II in Lyngenfjord on 8 October. (C) Acoustic record from the outer coastal area west of the island Loppa on 6 October. Locations of echograms marked with bold black lines in Figure 1. (a), (b), and (c) denote the bottom channel registrations in the nearest $10 \mathrm{~m}$ to the bottom. The volume backscattering strength threshold in the echo integrator, $\mathrm{Sv}, \mathrm{t},=-82 \mathrm{~dB}$ re $1 \mathrm{~m}^{-1}$. 


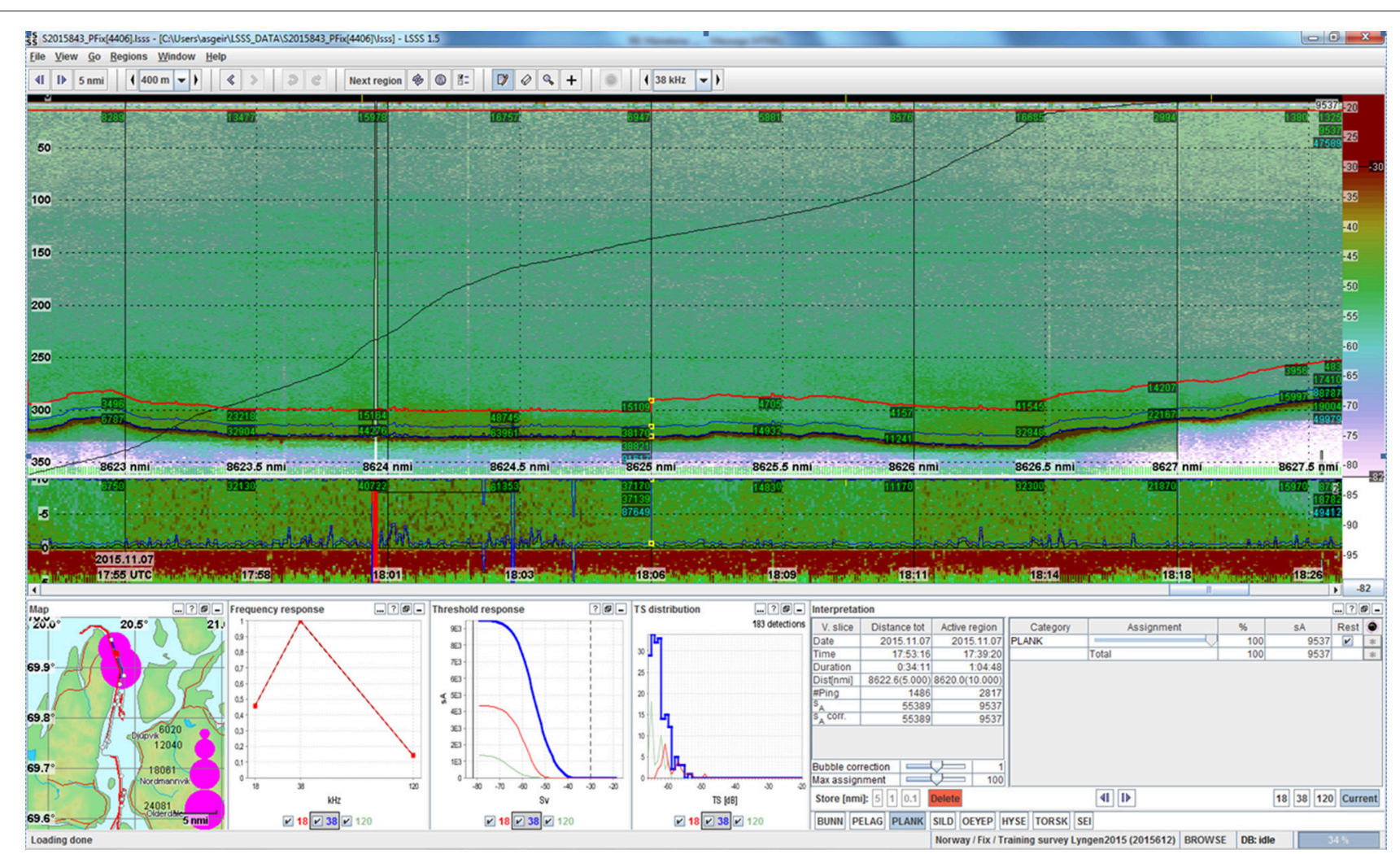

FIGURE 10 | Echogram from RV Helmer Hanssen recorded on 7 November 2015 just east of the northern tip of the Lyngen peninsula. Location of registrations is shown on the map in the lower left corner of the figure. The characteristic frequency response is shown next to the map. The threshold $\mathrm{Sv}, \mathrm{t}=-82 \mathrm{~dB}$ re $1 \mathrm{~m}{ }^{-1}$. Time $\sim 17: 55-18: 18$ UTC.

frequencies, i.e., maximum target strengths, between 18 and $38 \mathrm{kHz}$ at $17.5 \mathrm{~m}$ depth, very close to $38 \mathrm{kHz}$ at around $50 \mathrm{~m}$ depth, $17.5 \mathrm{~m}$ and slightly above $38 \mathrm{kHz}$ at $100 \mathrm{~m}$ depth. A slightly larger $0.30 \mathrm{~mm}$ radius sphere, is extremely close to resonance at $18 \mathrm{kHz}$ and $17.5 \mathrm{~m}$ depth, but near resonant at $38 \mathrm{kHz}$ at $100 \mathrm{~m}$ depth. More importantly, gas-filled spheres with ESRs of 0.45 , 0.50 , and $0.55 \mathrm{~mm}$ all have resonance frequencies close to $18 \mathrm{kHz}$ at depths around $100 \mathrm{~m}$, and close to $38 \mathrm{kHz}$ at $300 \mathrm{~m}$ depth with the $0.45 \mathrm{~mm}$ radius sphere closest to the $38-\mathrm{kHz}$ resonance peak at this depth (Figure 12). At $100 \mathrm{~m}$ depth, the $0.55 \mathrm{~mm}$ radius sphere is the closest to the resonance peak at $18 \mathrm{kHz}$. These theoretical considerations support the in situ acoustic data observations above (Figure 11), where $s_{\mathrm{A}}$ at $18 \mathrm{kHz}$ dominates in the upper $125 \mathrm{~m}$ of the water column and $\mathrm{RFR}_{18}$ peaks at around $55 \mathrm{~m}$ depth. However, the two models differ significantly in the peak resonance, the full model without any damping being much higher than the hybrid model. It has been argued that the membrane surrounding the pneumatophore adds considerable damping (Trevorrow et al., 2005), thus making the hybrid model more realistic.

The vertical distribution of the target strength, TS, based on the hybrid model shows distinct changes as bubble radius (a) changes in the range $0.10-0.55 \mathrm{~mm}$ (Figure 13). The vertical distribution of TS for the larger sized gas-inclusions is of particular interest (Figure 13, lower panel). Here, the peak TS at
$18 \mathrm{kHz}$ appears progressively deeper as the gas-inclusion radius increases from 0.35 to $0.55 \mathrm{~mm}$, a trend that continues for larger sized spheres (Supplementary Figure S2). Simultaneously, the depth range where TS at $18 \mathrm{kHz}$ dominates over 38 and $120 \mathrm{kHz}$ increases: TS at $18 \mathrm{kHz}$ is greater than the TS at 38 and $120 \mathrm{kHz}$ over the depth range of $\sim 20-50 \mathrm{~m}$ for a gas-inclusion radius of $0.35 \mathrm{~mm}, \sim 20-75 \mathrm{~m}$ for a radius of $0.45 \mathrm{~mm}$, and $\sim 20-140 \mathrm{~m}$ for a radius of $0.55 \mathrm{~mm}$. Further, the depth where the TS at $18 \mathrm{kHz}$ becomes lower than the TS at $38 \mathrm{kHz}$ is $\sim 120 \mathrm{~m}$ and $\sim 145 \mathrm{~m}$ for a gas-inclusion radius of 0.50 and $0.55 \mathrm{~mm}$ respectively, while for gas-inclusions having a radius of 0.60 and $0.65 \mathrm{~mm}$ the corresponding depths are clearly deeper, $\sim 175$ and $205 \mathrm{~m}$ respectively (Supplementary Figure S2). Interestingly, for the gasinclusions with a radius of 0.50 and $0.55 \mathrm{~mm}$, the shapes and features of target strengths vs. depth curves compare reasonably well with the in-situ data in Figure 11 where this transition is located at $\sim 130 \mathrm{~m}$ depth. The in situ vertical distributions of $\mathrm{s}_{\mathrm{A}}$ (Figure 11) are most similar to the TS distributions with radius of gas-inclusions in the range $0.45-0.55 \mathrm{~mm}$. It is noted that the TS at $120 \mathrm{kHz}$ were reasonably constant over the water column for most of the bubble radiuses $(a=0.20-0.55 \mathrm{~mm}$ ) as displayed in Figure 13 and thus also far from resonance at this frequency. Hence, both the 38 and $120 \mathrm{kHz}$ TS distributions were used to explore the estimated density of pneumatophores present in the water column (Figures 14A,B). 

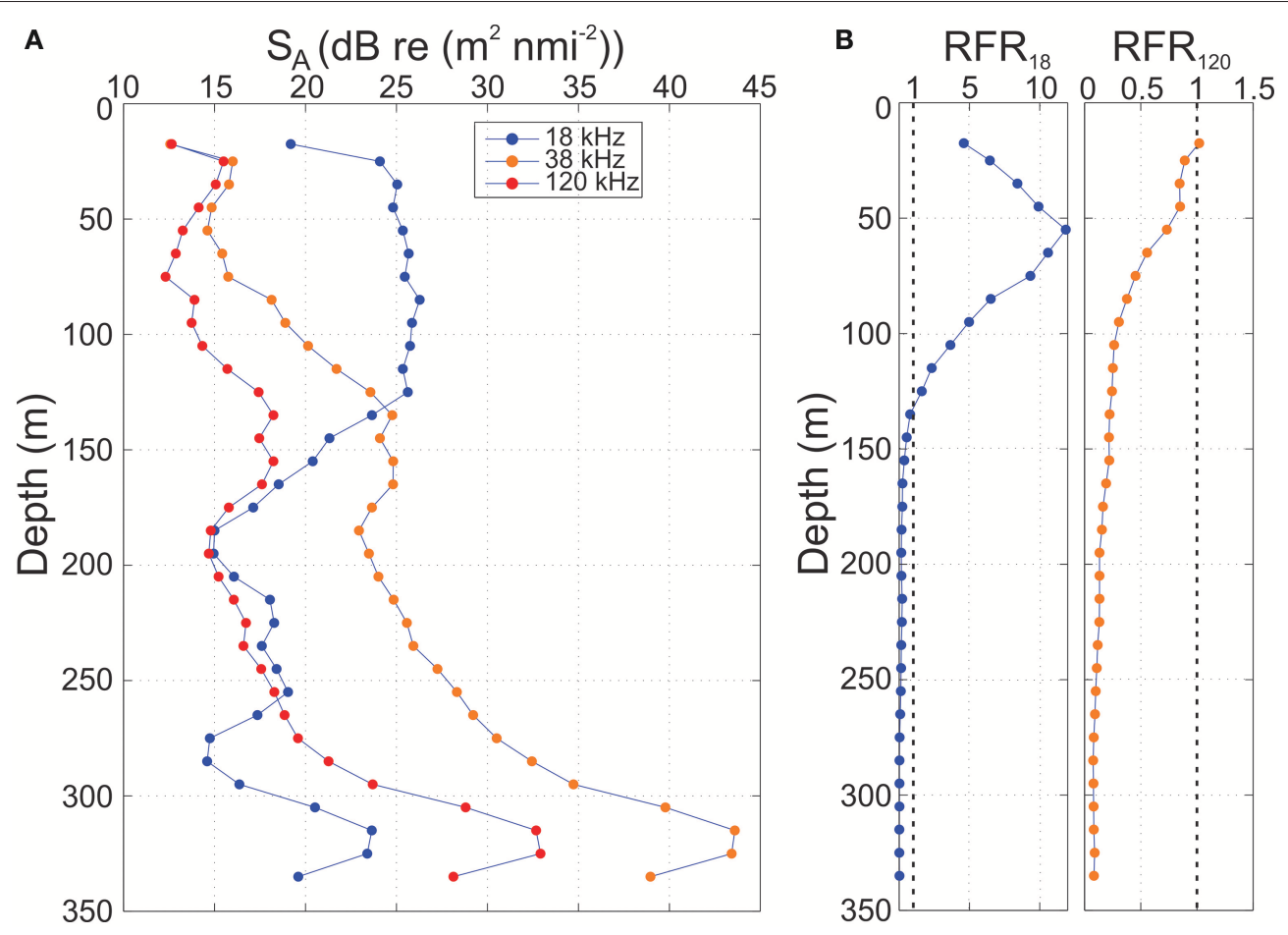

FIGURE 11 | (A) Vertical structure in acoustic backscatter, presented as nautical area scattering strength, $\mathrm{S}_{\mathrm{A}}=10 \mathrm{log}_{10}\left(\mathrm{~S}_{\mathrm{A}}\right)$, over a $3.5 \mathrm{nmi}$ distance (Log 8623.4-8626.9, cf. Figure 10) for the frequencies 18, 38, and $120 \mathrm{kHz}$ from RV Helmer Hanssen on 7 November 2015. (B) Relative Frequency Response RFR for 18 and $120 \mathrm{kHz}$ respectively vs. depth. Stippled vertical lines indicates when the RFR ratio is equal to 1 . The volume backscattering strength threshold $\mathrm{S}_{\mathrm{V}, \mathrm{t}}=-82 \mathrm{~dB}$ re $1 \mathrm{~m}^{-1}$. Note, $\mathrm{x}$-axes are unequal.

Based on the $38-\mathrm{kHz}$ data, water column estimated volume densities $\left(\mathrm{V}_{\text {Dens }}\right)$ of siphonophore pneumatophores with gasinclusion bubble radius $(a)$ of $0.45,0.50$ and $0.55 \mathrm{~mm}$ were in the range $\sim 0.2-20.5$ colonies $\cdot \mathrm{m}^{-3}$. At $25-265 \mathrm{~m}$ depth, average estimated density was $\sim 0.5$ colonies $\cdot \mathrm{m}^{-3}$, with a maximum of $\sim 1.0$ colony $\cdot \mathrm{m}^{-3}$ around $135 \mathrm{~m}$ depth. Below $265 \mathrm{~m}$ densities increased and peaked around $325 \mathrm{~m}$ depth close to the bottom, with densities in the range 9-20.5 colonies $\cdot \mathrm{m}^{-3}$ (Figure 14A). For $120 \mathrm{kHz}$ the trends in the data are very similar to $38 \mathrm{kHz}$, but computed densities were overall somewhat lower and varied less between given gas bubble sizes (i.e., 12.6-18.2 colonies $\cdot \mathrm{m}^{-3}$ ) in the range $315-325 \mathrm{~m}$ (Figure 14B). For both frequencies it is noted that number of pneumatophores increase in the depth region $\sim 250-295 \mathrm{~m}$ and here the number of pneumatophores per unit volume were in the range $0.4-2.5$ colonies $\cdot \mathrm{m}^{-3}$.

\section{Genetic Analysis}

Length of the obtained genetic marker sequences was 983-1045 bp for COI and 314-617 bp for 16S. Trimmed alignments were $969 \mathrm{bp}$ for COI (all 7 sequences) and $480 \mathrm{bp}$ for $16 \mathrm{~S}$ (disregarding the shortest sequence). Pairwise comparisons showed that the COI sequences differed by $0-2$ bp $(0-0.2 \%)$ and the $16 \mathrm{~S}$ sequences by $1-5$ bp $(0-1.0 \%)$. For COI, BLAST identified seven $N$. cara COI sequences (GenBank accession no. GQ120027.1, GQ120025.1, GQ120024.1, GQ120023.1, GQ120029.1, GQ120028.1, and GQ120026.1) as the closest matches, with 99.5-99.7\% similarity (alignment length 966$971 \mathrm{bp}$ ), confirming our tentative identification based on the collected material and the images. BLAST found no close match for the $16 \mathrm{~S}$ sequences, the closest hit being Agalma clausi 16S, accession no. AY935270, at 89\% similarity.

\section{DISCUSSION}

The current material documents exceptional abundances of three species of jellies occurring within the northern Norwegian study area during a relatively short time period in the autumn 2015. Substantial quantities of ctenophores (Beroe cf. cucumis) were caught with trawls, attracting considerable media attention.

Concurrent with the ctenophore catches, research vessels and local fishermen operating in the area experienced heavy fouling of their equipment by a red "slime." The descriptions of the fouling material were very similar to those provided by fishermen from the Gulf of Maine during a $N$. cara mass occurrence in 1975 (described in Rogers, 1976a). Morphological examination of the current fouling material suggested that it was probably also attributable to physonect siphonophores of the genus Nanomia.

One of the trawl hauls also included numerous specimens of the conspicuous hydromedusa $M$. rotunda-a widely occurring, but relatively rarely observed species. $M$. rotunda is considered as a deep-sea oceanic medusa (Cornelius, 1995), but is also 

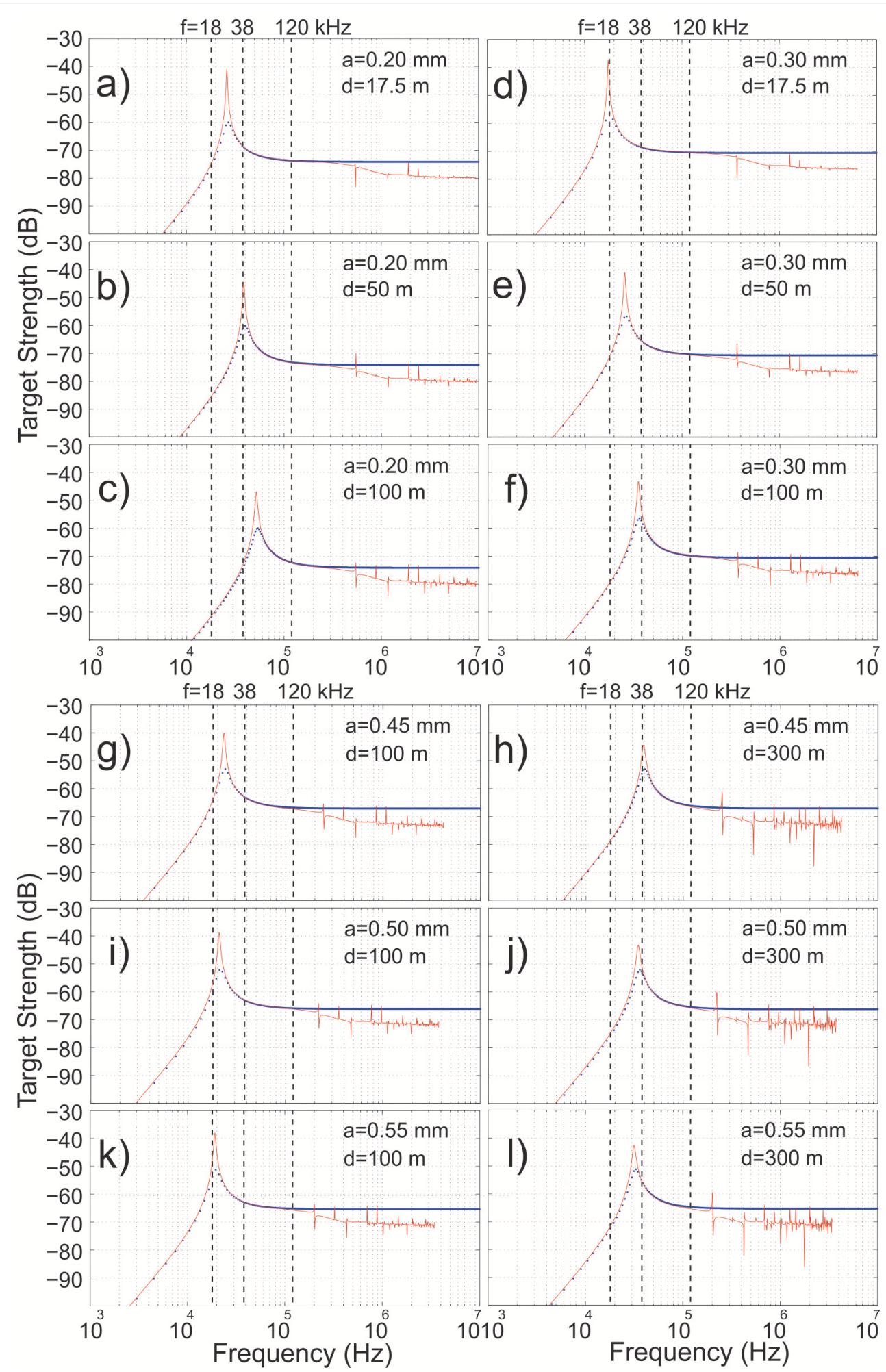

FIGURE 12 | Modeled target strength, TS [dB re $1 \mathrm{~m}^{-2}$ ] versus frequency ( $\mathrm{f}$ ) for the full modal series solution Anderson (1950) [red line] and the damped hybrid model

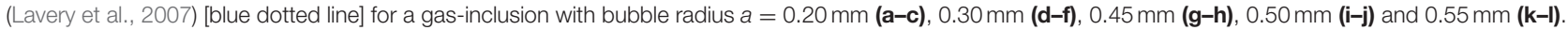
Upper panels (a-f): Small gas-bubbles 0.20 and $0.30 \mathrm{~mm}$ at 17.5, 50 and $100 \mathrm{~m}$ depth. Lower panels (g-l): Larger gas-bubbles $0.45,0.50$ and $0.55 \mathrm{~mm}$ at 100 and $300 \mathrm{~m}$ depth. 

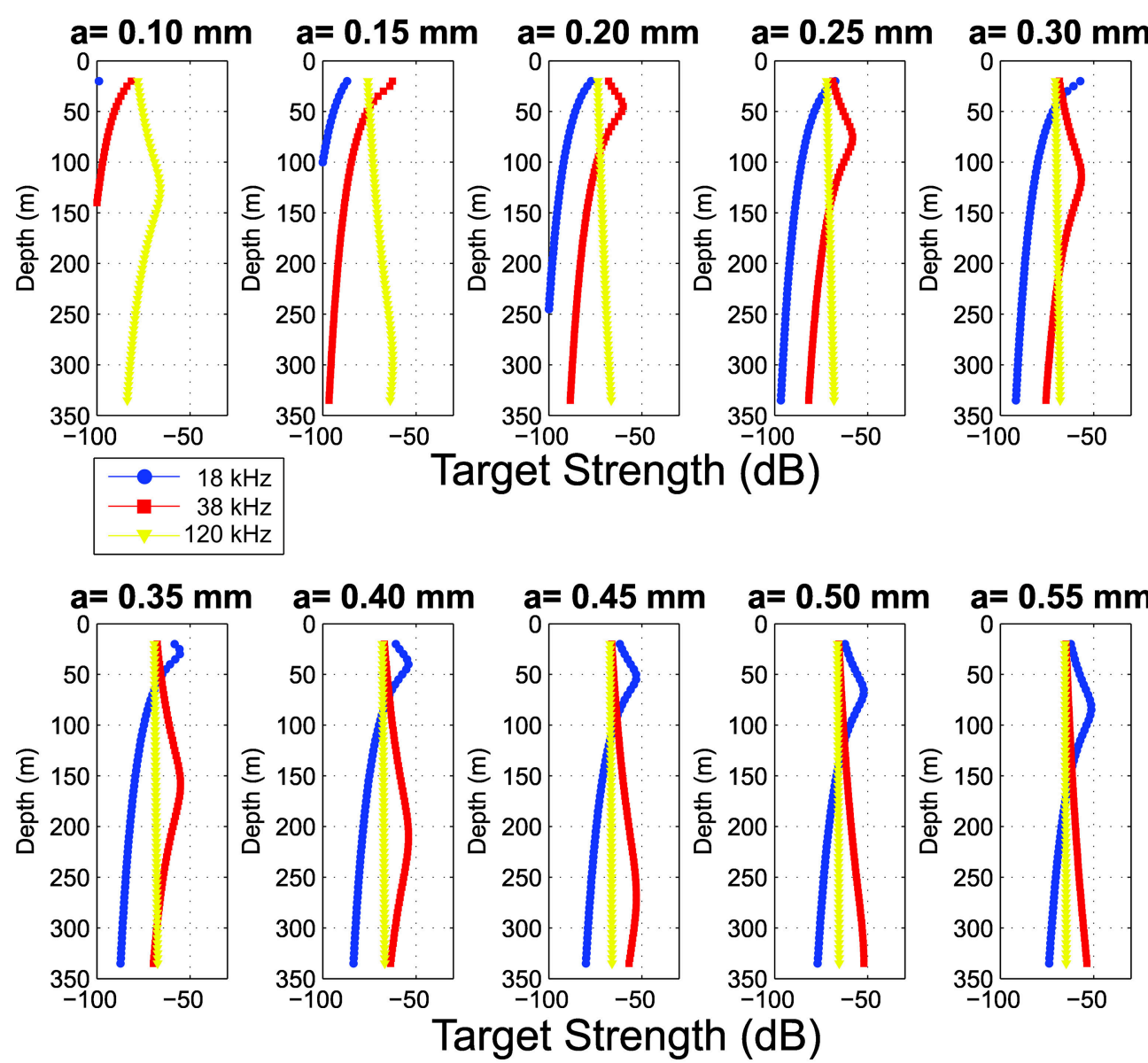

FIGURE 13 | Depth stratified estimated target strength, TS [dB re $1 \mathrm{~m}^{-2}$ ] based on the hybrid damped model for siphonophore gas-inclusions with bubble radius (a) in the range $0.1-0.55 \mathrm{~mm}$ in steps of $0.05 \mathrm{~mm}$.

known from West-Norwegian fjords (Hosia and Båmstedt, 2007). Its rather inconspicuous hydroid stage is known to occur in tropical to boreal Atlantic up to Iceland and Greenland, as well as the Barents- and Kara Seas in the Arctic region (reviewed in Cornelius, 1995; Schuchert, 2001).

The bottom trawl data obtained by RV Håkon Mosby indicates that the concurrent abundances of the larger jellyfish, the scyphomedusae Cyanea, Aurelia, and Periphylla, in the study area were in no way extraordinary or significantly different compared to the average abundance in the larger area of the north-Norwegian fjords from Andøya in the south-west to the Varangerfjord in the north-east.

The current data do not allow us to ascertain whether the observed accumulations of Nanomia, Beroe, and Modeeria were true blooms resulting from population increases or the result of advective or behavioral aggregation. However, there was no indication that any of the species were particularly associated with Atlantic water, which would have suggested advection from offshore as described in the next section. The three species differ in terms of their biology and the same explanation for the observed high abundances may not apply to all of them. Nanomia and Beroe spp. are holopelagic, while $M$. rotunda has a benthic hydroid stage. The species also differ in their trophic ecology and dietary preferences.

\section{Local Oceanographic Processes}

During this study of the Lyngen-Kvænangen fjord system, the salinity of the deep-waters seawards of the fjord system was clearly higher than salinities in the basin waters of the fjords deeper than $\sim 200 \mathrm{~m}$. This suggests there had been no recent renewal of the basin waters of the fjords prior to the events monitored in October and November 2015. The oxygen content of the near bottom water of the fjord basins (Arnøya and Lyngen Basin I), was also markedly lower than observed further seawards, supporting this interpretation. However, at intermediate depths (75-150 m), both salinity and temperature conditions were similar in the deep shelf areas and the Arnøya basin. This indicates similar density of water masses within this depth range (Supplementary Figure S3), and could potentially facilitate exchange of water masses between nearby fjords and the outer coastal regions. Also in November, the temperature, salinity, and density $\left(\sigma \mathrm{t}-\mathrm{kg} \cdot \mathrm{m}^{-3}\right.$ ) profiles in Kvænangen (HH1687) and in Lyngenfjord Basin I (HH1673) were nearly identical over the depth range given above (Supplementary Figure S4), suggesting 


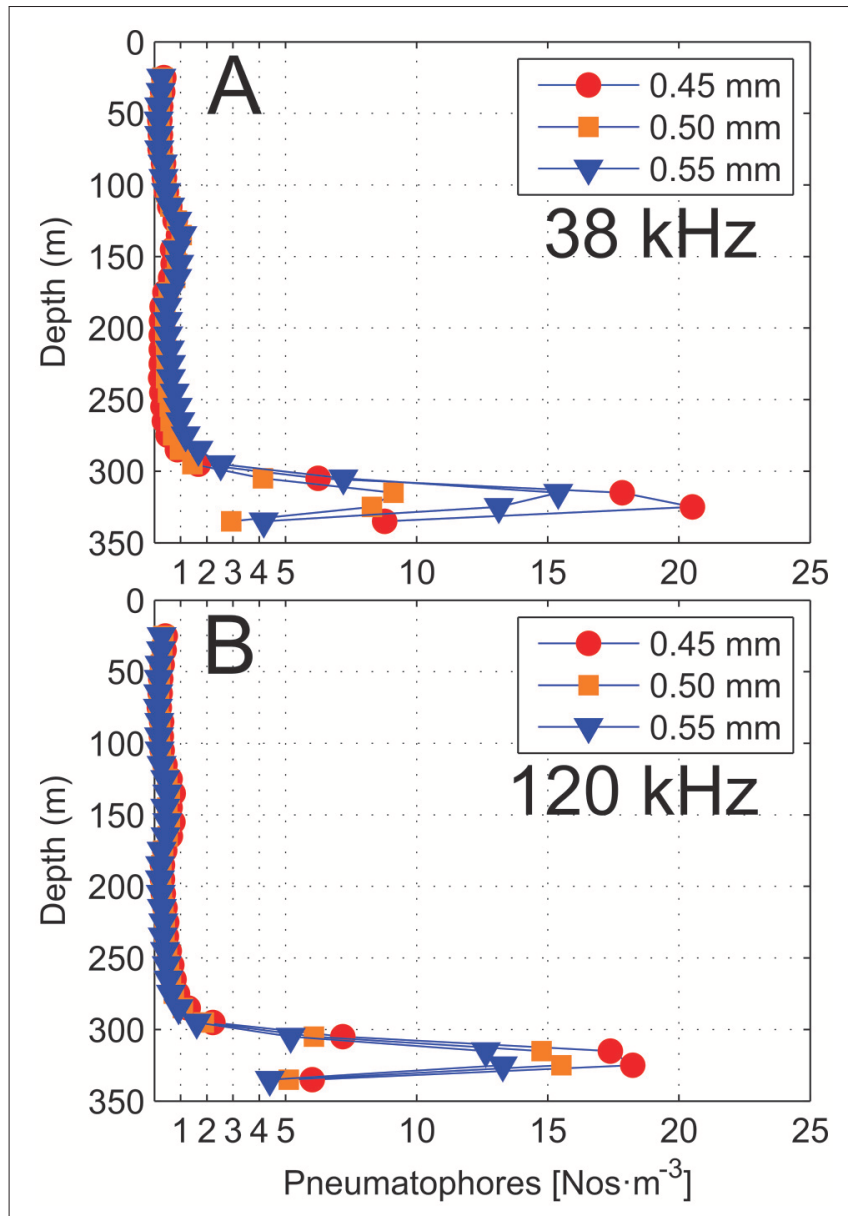

FIGURE 14 | Number of Nanomia pneumatophores [Nos.m ${ }^{-3}$ ] as determined based on the theoretical depth dependent target strengths (TS) using the hybrid damped model for three different sizes of siphonophore gas-inclusions with bubble radius $0.45,0.50$, and $0.55 \mathrm{~mm}$. Computations based on (A) $38 \mathrm{kHz}$ and (B) $120 \mathrm{kHz}$.

that both fjord basins were influenced by the same type of water of outer coastal origin. The water masses in the North Norwegian fjords in the Troms region are known to be tightly integrated with and affected by the Norwegian Coastal Current (NCC) and North Atlantic Current (NAC) (Falkenhaug et al., 1995; Svendsen, 1995; Wassmann et al., 1996). Both abrupt exchange of waters masses and more subtle introductions of outer coastal water and deep water have been documented on multiple occasions during the year in Balsfjorden (Wassmann et al., 2000), despite a very shallow sill. In contrast, Lyngenfjord and Kvænangen, are open fjords with deep sills, situated in close proximity to the shelf areas to the north. The shallow connections between these two fjords (cf. Figure 1B) most likely limit the exchange of deep and intermediate water masses between their basins. However, Espeland et al. (2015) used nested ocean circulation models to show that surface water could be displaced north-eastwards from Lyngenfjord through the narrow sounds between the two fjords. Similar hydrographic conditions in the upper $\sim 170 \mathrm{~m}$ of the water column (Supplementary Figures S3, S4, Results section) are probably a result of regional oceanographic processes involving coastal water masses influencing both fjords at intermediate depths in a near identical manner.

Changes in fjord ecosystems, such as coastal water darkening which might favor tactile predators over visual ones (cf. Aksnes et al., 2009), might be an additional effect that could increase the frequency of bloom occurrences, although we have currently no new data that can support such ecosystem change.

\section{The Ctenophore Beroe}

The ctenophores were identified as Beroe cf. cucumis based on photos of the trawl catch. Beroe cucumis is found in the North Atlantic and the Arctic Ocean, and is common along the entire Norwegian coast. However, it is worthwhile to note that its congener B. abyssicola also occurs in the Boreal North Atlantic and Norwegian Arctic, and can have a rather similar habitus (Licandro et al., 2015; Hosia and Majaneva, unpublished data).

Beroe spp. are assumed to largely feed on other ctenophores (reviewed in Purcell, 1991, 1997) and the high biomass of Beroe observed in the trawls in Lyngen and Kvænangen indicates the presence of large amounts of ctenophore prey in the area. We have no information on abundances of other ctenophore species during or prior to our observations in November 2015. However, dense blooms of the lobate ctenophore Bolinopsis infundibulum are common in coastal waters of northern Norway during spring and summer until August (Falkenhaug, 1996). It is thus likely that the high biomass of B. cucumis in Lyngenfjord had been sustained by feeding on blooms of $B$. infundibulum earlier in the season.

The fate of ctenophore populations during winter is scarcely described in the literature and it is often believed that a small number of individuals overwinter in the water column in sheltered areas (Costello et al., 2006). Overwintering of ctenophores in deeper layers, close to the bottom, has previously been reported for B. ovata and Mertensia ovum in the Canadian Arctic (Siferd and Conover, 1992), for B. cucumis in northern Norway (Falkenhaug, 1996), and for Mnemiopsis leidyi in Argentina (Costello and Mianzan, 2003). To remain in deeper waters below sill level may be an overwintering strategy of Beroe spp. in high latitudes. In Malangen fjord (northern Norway), B. cucumis performed a seasonal vertical migration, from distributions above $50 \mathrm{~m}$ in summer (May-July), to below $200 \mathrm{~m}$ from September to April (Falkenhaug, 1996). The observed high abundance of B. cucumis in the deeper basins of the Lyngen and Kvænangen fjords during late fall and early winter may thus be explained by a combination of high local production in the surface water during summer and a seasonal vertical migration during autumn. This will lead to accumulations of B. cucumis in the deeper basins where the advective losses are low. These basins serve as overwintering refugia that seed population growth during the following productive season (Costello et al., 2006).

\section{The Siphonophore Nanomia}

COI sequences from specimens in the fouling material provided a match with $N$. cara sequences from GenBank. $N$. cara (sensu Kirkpatrick and Pugh, 1984) is a boreal North Atlantic species frequently observed in the north east Atlantic, northern North 
Sea, and Skagerrak, as well as in western Norwegian fjords (Kirkpatrick and Pugh, 1984; Hosia and Båmstedt, 2008).

To our knowledge, this is the first report of a mass occurrence of Nanomia sp. from Norwegian waters. However, information from a retired local fisherman (Jarle Mollan [age 83], Skjervøy, Troms, pers. comm.) suggests that at least one similar event occurred during autumn/winter 1959/1960 in the current study area. At that time, shrimp trawlers got their trawls severely contaminated with a similar type of slime and had to cook the trawl nets twice with the onboard shrimp cooker before a new haul could be made. They were nevertheless still able to catch shrimps, although a longer towing time was required. Mollan also states that over the last 3-5 years, fishermen have observed increased amounts of the "round marble-like" hydromedusae (probably M. rotunda), and the "cucumber-like ctenophore" (Beroe sp.).

Harmful blooms of $N$. cara have been previously reported from the Gulf of Maine in 1975-1976 and 1992-1993 (Rogers, 1976a,b; Rogers et al., 1978; Mills, 1995). In the NE Atlantic, abundant Nanomia sp. have been reported from Valencia Harbour, Ireland, (as Cupulita sarsii) in 1897-1898 (Browne et al., 1898), the Salcombe estuary, England, in 1929 (Berrill, 1930), off Plymouth, England, in 1930 (Russell, 1933) (as Stephanomia bijuga), as well as from Bantry Bay, Ireland, in June 2014 (Haberlin et al., 2016).

Further south on the West-Norwegian coast, most fjords appear to have year-round resident populations of Nanomia sp, and it is also common in the coastal waters outside the fjords, as well as further offshore in the North East Atlantic (Williams and Conway, 1981; Hosia et al., 2008; Licandro et al., 2015) and occurring all the way up to the Fram Strait (Hosia, unpublished data). The species could therefore potentially be present in the Lyngenfjord-Kvænangen area year-round. Particularly favorable local environmental conditions, including higher prey availability in the fjord basins compared to the shallower shelf areas to the north, possibly in combination with restricted vertical migration by the siphonophores, limited exchange of deep basin waters during the period of the bloom, and the preference of adult colonies to primarily reside in the deeper parts of the fjord system, could have acted in concert and promoted the accumulation and growth of colonies in the deep basins. Additionally, shallow sills possibly prevented dispersal of these organisms to the inner part of the fjord system. The observed distribution pattern could be maintained by the prevailing currents, which favor seaward transport in the surface layers and possibly weak inflow at intermediate depths. The observations of identical acoustic structures in the deep depression on the northern shelf outside the fjord system (Figures 8B, 9C) could be occurring in a similar way, by entrapment and enrichment of colonies as these can vertically migrate to their preferred deep-water habitat to either feed or seek shelter.

Although relatively ubiquitous in Norwegian coastal waters, Nanomia is potentially underreported in plankton surveys, as the colonies tend to break apart in plankton nets, hindering identification and enumeration. Nanomia spp. may also be able to avoid slow moving plankton nets to a degree (Warren et al., 2001 ), with escape swimming speeds of up to $\sim 60 \mathrm{~mm} \cdot \mathrm{s}^{-1}$ measured (Costello et al., 2015). Physonect colonies consist of a long stem with a gas filled pneumatophore at its apex and various specialized zooids arranged in a species-specific manner along it. Fully grown $N$. cara colonies have been reported to reach lengths in excess of $1 \mathrm{~m}$ (Rogers et al., 1978; Mapstone, 2009). Due to their size and fragility, one would not normally expect to catch identifiable colonies of Nanomia with fish trawls and it was also clear from examination of the fouling material that the colonies had lost most of their zooids. However, their long stems had become entwined with the gear, resulting in the filamentous fouling mass.

Information on the abundance of non-gelatinous zooplankton during the observed mass occurrence of Nanomia is lacking and it is not known what the siphonophores had been feeding on. The zooplankton abundance in high latitudes follows a strong seasonal pattern, with peak production restricted to a relatively short summer season. The observed mass-occurrences of Nanomia occurred after the main productive season when zooplankton abundances are generally low in upper waters. However, large abundances of dormant zooplankton are often found below sill level in fjords during winter (Falkenhaug et al., 1997a), and the deep basins of fjords have been found to hold local populations of overwintering C. finmarchicus (Bagøien et al., 2001). This is especially true in advective fjords, where the zooplankton are supplied by advection (Matthews and Heimdal, 1980; Falkenhaug et al., 1995). The winter zooplankton community in north Norwegian fjords is dominated by large copepods (Calanus finmarchicus, Metridia longa, Euchaeta spp.), euphausiids, and pelagic decapods (Pasiphaea multidentata) (Hopkins et al., 1984; Falkenhaug et al., 1997a,b; Pedersen et al., 2015), which are all potential prey of siphonophores.

\section{Acoustics}

While the extent of observed fouling suggested the presence of extraordinary numbers of physonect siphonophores, unfortunately no quantitative physical samples were available for estimating abundances or distribution. However, physonect colonies possess a gas-filled pneumatophore and it is considered an important source of acoustic scattering (Barham, 1963, 1966; Warren et al., 2001; Benfield et al., 2003; Trevorrow et al., 2005; Lavery et al., 2007). Acoustic data supported the presence of high abundances of physonect siphonophores and abundant agalmid physonects were observed on video recordings made in the area.

The extreme backscattering values, $\mathrm{s}_{\mathrm{A}}$, recorded in various part of the Lyngenfjord and Kvænangen during October and November 2015 are comparable to the total integrated backscatter of migrating herring observed south of the Lofoten area (Zedel et al., 2003, their Figure 1). However, the frequency response associated with these very dense registrations shows a peak at $38 \mathrm{kHz}(>150 \mathrm{~m})$ and much lower response at both 18 and $120 \mathrm{kHz}$. This is different from herring for which the frequency response of typical schools peaks at $18 \mathrm{kHz}$ and decreases with increasing frequency in the range 18$200 \mathrm{kHz}$ (see Gorska et al., 2004; Korneliussen et al., 2009). The nature of schooling herring (cf. Huse and Ona, 1996; 
Huse and Korneliussen, 2000; Zedel et al., 2003; Korneliussen et al., 2009) is also quite different from what was observed in Lyngen, and very few herring were caught in the trawls in the Lyngenfjord and Kvænangen area during the present investigation.

The type of registrations visualized by the echosounders, diffuse but strong, and mostly concentrated below $150 \mathrm{~m}$ depth, was also unique. There was strong scattering at $38 \mathrm{kHz}$ close to the bottom during daytime, with indications of diel vertical migration (DVM). The acoustic observations on 7 November 2015 were particularly strong, and evident also in the epipelagic zone (Figure 10). These recordings were aquired in the evening at $\sim 18: 55-19: 18$ local time, after the sunset at 14:07, suggesting that part of the Nanomia population migrated to shallower depths in the evening. A month earlier, dense registrations close to the bottom, lifting off the bottom and partly penetrating shallower depths during night, were also observed, although to a lesser degree. These observations suggest the presence of a viable Nanomia population performing DVM. Nanomia spp. are considered diel vertical migrators (Mackie, 1985; Robison et al., 1998; Hosia and Båmstedt, 2008), and during the 1993 bloom in Wilkinson Basin, large numbers of colonies were also observed occupying the lower half of the water column by day and migrating toward the surface and spreading over the entire water column by night (Mills, 1995).

The densest registrations during the current mass occurrence were associated with the deepest part of the fjord basins and shallow sills appeared to act as barriers to dispersal (cf. Figure 9B). This fit well with what is known about the vertical distribution of Nanomia from previous observations. Aggregations of $N$. cara close to the bottom have been observed in western Norwegian fjords $(\sim 600-700 \mathrm{~m}$ deep), as well as in the Gulf of Maine (Mills, 1995; Hosia and Båmstedt, 2008). Fjord sills can promote the retention of zooplankton in the fjord basins and in western Norwegian fjords physonect siphonophores, most likely Nanomia, have been observed to have the weighted mean depth of their distributions below sill depth (Hosia and Båmstedt, 2008).

\section{Size of Gas-Inclusions}

There is in general sparse information available on the exact size of Nanomia spp. pneumatophores. The few measurements made during this study suggest a gas-inclusion ESR in the range $0.34-0.56 \mathrm{~mm}$, the largest one being the pneumatophore that was photographed within 3 weeks of collection on 23 October 2015 (Figure 5). However, since most of the material was stored in formalin for a year prior to measurement and many of the pneumatophores were at this point clearly deflated, we suspect these measurements are in the lower range of the actual sizes present in situ. The theoretical considerations based on the full modal series solution (Anderson, 1950) and the hybrid damped scattering models suggest that gas inclusion radius in the range $0.45-0.55 \mathrm{~mm}$ is in reasonable agreement with the acoustic data recorded in situ. Most existing measurements of pneumatophores have also been done ex situ after retrieval of specimens. Barham (1963) reports on 50 pneumatophores of Nanomia bijuga having an average ESR of $\sim 0.56 \mathrm{~mm}$ [our own computation based on numbers in Barham (1963)] after 3 weeks of fixation in $10 \%$ formalin. Warren et al. (2001) reported that scattering levels of individual siphonophores measured at depth were consistent with scattering "from a gas inclusion with a diameter of about $1 \mathrm{~mm}$ " and measured similar pneumatophore diameters from animals captured by net tows in the upper $20 \mathrm{~m}$ of the water column $(\mathrm{N}<5)$. These diameters are not given, nor is it explicitly stated whether they were measured alive directly upon retrieval, or after fixation and storage. Benfield et al. (2003) measured the pneumatophores of physonect siphonula larvae in situ using a Video Plankton Recorder (VPR), as well as from preserved individuals caught with a MOCNESS net sampling system (Wiebe et al., 1985). The diameter of siphonula pneumatophores ranged from $0.1-0.4 \mathrm{~mm}$, with the MOCNESS collected individuals showing somewhat elevated frequencies of smaller diameter gas-inclusions, probably due to post-collection loss of gas (Benfield et al., 2003). [Note: while (Benfield et al., 2003) suspected that the siphonulae they imaged belonged to the genus Nanomia based on the presence of adult $N$. cara in the waters of the Gulf of Maine during their cruise, the preserved siphonula depicted in their Figure $2 \mathrm{~d}$ is an athorybia larva of Agalma sp.]. Notably, their data indicate that the diameter of the gas-filled pneumatophores did not appear to change much with depth in the upper $150 \mathrm{~m}$ of the water column. Siphonophores are believed to be able to maintain the diameter of their pneumatophore by secreting or absorbing carbon monoxide gas (Mackie et al., 1987), which also seems to apply for the siphonula larvae (Benfield et al., 2003). The pneumatophores in the genus Nanomia also possess an apical pore through which carbon monoxide can be released (Pickwell et al., 1964).

\section{Densities and Vertical Distribution of Nanomia Colonies}

The estimated density of Nanomia colonies based on the acoustic data in the current study (Figure 10 and map therein), was $\sim 0.2$ to 1.0 colonies $\cdot \mathrm{m}^{-3}$ at $25-265 \mathrm{~m}$ depth, and up to $\sim 18$ 20 colonies $\cdot \mathrm{m}^{-3}$ in the deepest part of the water column at $\sim 320 \mathrm{~m}$ depth, slightly depending on the frequency used for these computations. These numbers are comparable to previous observations on Nanomia densities. November density of $N$. bijuga in Glacier Bay, Knight Inlet, Canada was estimated as 0.13 colonies $\cdot \mathrm{m}^{-3}$ in a scattering layer around $30-65 \mathrm{~m}$ depth using a BIONESS net sampling system (Trevorrow et al., 2005). An independent estimate based on an acoustic-statistical technique dubbed "critical density analysis" gave a very similar estimate of 0.14 colonies $\cdot \mathrm{m}^{-3}$ (Trevorrow et al., 2005). $\mathrm{N}$. bijuga abundances with a mean of $\sim 0.05$ colonies $\cdot \mathrm{m}^{-3}$ (up to 1 colony $\cdot \mathrm{m}^{-3}$ ) were estimated from $\mathrm{ROV}$ video recordings made in Monterey Bay (Robison et al., 1998). However, these densities are considerably lower than the $1-10$ colonies $\cdot \mathrm{m}^{-3}$ estimated acoustically for N. cara in the Gulf of Maine (Warren et al., 2001; Benfield et al., 2003). Similarly, in the Gulf of Maine, earlier submersible observations made during Nanomia 
blooms have suggested densities of $1-8$ colonies $\cdot \mathrm{m}^{-3}$, with the densest concentrations often occurring between 3 and $45 \mathrm{~m}$ above the bottom at 120-180 m (Rogers et al., 1978). Densities of 9.8 colonies $\cdot \mathrm{m}^{-3}$ based on net sampling were recorded from Bantry Bay, Ireland, in June 2014 (Haberlin et al., 2016). The highest reported densities come from the Gulf of Maine in September 1993, where 50-100 colonies $\cdot \mathrm{m}^{-3}$ were reported congregating in the $20 \mathrm{~m}$ above the bottom at $270 \mathrm{~m}$ (Mills, 1995). This kind of swarming may be behavioral, resulting from siphonophores altering their swimming in response to prey concentrations (pers. com. Biggs in Rogers, 1976a).

It is realized that differences in colony size may impact the overall size distribution of pneumatophores and represent an uncertainty regarding the density of colonies estimated from the acoustic data during the current investigations. Backscattered intensity also originates from organisms with gas-inclusions that deviate somewhat from the expected size range 0.45$0.55 \mathrm{~mm}$ radius (cf. Barham, 1963; sections Acoustic Scattering Models, Siphonophore Gas-Inclusion Target Strengths and Abundance and Size of Gas-Inclusions), and even some smaller gas-inclusions might be resonant in the shallower regions of the water column (cf. Figures 12, 13). While no systematic measurements on change in pneumatophore size during growth and development exist, it is clear that there is an increase in size from the rudimentary pneumatophore developed within days of fertilization to the pneumatophores of mature colonies and that pneumatophore size may continue to increase with growth of the colony. We know very little about the reproductive cycles of Nanomia in subarctic waters and how the population developed more than a month into the bloom. While there is no evidence that siphonula larvae were present in the Lyngen area during the period covered by these investigations, the GoPro video recordings suggest the presence of slightly variable colony sizes. However, it is believed that siphonophores with gas-inclusions $\leq 0.30 \mathrm{~mm}$ radius were not abundant during the latter part of the bloom, for which the above referred densities were computed. It is noted that at maximum depth of the GoPro recordings $(265 \mathrm{~m}$, cf. Figure 7$)$, there were maximally observed 1-3 colonies in the field of view of the GoPro camera (distance between upper and lower CTD frame equals $82.5 \mathrm{~cm}$ ). This would be close to an observed volume of $\sim 1 \mathrm{~m}^{3}$, if extended to three dimensions, hence very close to the densities computed by the acoustic method at this depth.

Mixed sizes of $N$. cara colonies ranging in length from 0.2 to $3.7 \mathrm{~m}$ were also observed in June 1976 in the Gulf of Maine, with the largest colonies having over 200 feeding polyps (gastrozooids) and 30-40 swimming bells (nectophores) (Rogers et al., 1978). In high density locations, colonies of varying sizes were often present, while in more peripheral low-density areas colonies were generally smaller, 20 to $40 \mathrm{~cm}$ in length (Rogers et al., 1978). The vertical distribution of the colonies also changed with size, with smaller colonies found higher in the water column than the larger ones. Benfield et al. (2003) also observed adult colonies co-occurring with the siphonula larvae, but in much lower densities.

\section{Post-cruise Observations and Fate of the Siphonophore Bloom}

Considering the predatory impact of Beroe and Nanomia on their respective prey, it is questionable whether the populations would be able to maintain the high biomasses observed over winter. While many jellies are resistant to starvation and capable of shrinking during limited nutrition, food limitation may be a factor contributing to the eventual collapse of gelatinous zooplankton blooms (Pitt et al., 2014). The gelatinous biomass may also end up consumed by pelagic predators or, ultimately, benthic scavengers. Gelatinous carcasses sinking to the seafloor may be rapidly eaten (Sweetman et al., 2014) and can also contribute to increased oxygen demand and altered nutrient dynamics in the sediment (West et al., 2009).

Since numerous vigorously swimming colonies were observed on the video recordings on 9 November, there is reason to believe that the $N$. cara population was still alive toward the end of the observation period. On the night between 26/27 November, at the start of the polar night, RV Helmer Hanssen revisited the area briefly. No quantitative acoustic data were recorded, but some screen-dumps of the EK60/ER60 echosounder main screen were obtained during a pass through the area, which occurred around midnight (Figure 15). Very dense acoustic registrations were observed close to the bottom and the strong acoustic layer appeared limited to below $100 \mathrm{~m}$ depth, with very little backscatter at shallower depths. This vertical distribution differs from that observed 20 days earlier on 7 November, and suggests less DVM activity by the siphonophore population.

The Lyngen area was visited again in December 2015 by RV Johan Ruud undertaking shrimp trawl experiments, and feedback from the cruise participants suggests there were less jellies registered in the trawl samples and by the echosounder compared to the situation in November. Nevertheless, some fishermen in Lyngen continued to report on problems with red slime on their fishing gear and that fish normally present had not returned to the "contaminated" areas in January 2016. We know of no further reports of the fouling slime from later in 2016 and no blooms were reported during autumn-winter of that year.

\section{Potential Consequences}

Large accumulations of gelatinous zooplankton in the fjords may have negative impacts on both fisheries and aquaculture, and the mass occurrence of siphonophores did indeed have consequences for local fishermen that depend on the local fjord stocks of fish and shrimps. The heavy fouling of fishing gear, loss of fishing opportunities, and possibly the avoidance of contaminated areas by fish, all represent income loss. The 1975 N. cara bloom in the Gulf of Maine was reported to foul fishing gear and even clog trawl nets, with the estimated losses to the fishing industry as high as \$300 000 (Rogers, 1976a,b). While we are currently not aware of Nanomia spp. having interfered with aquaculture in the sense of having adverse effects or lead to increased mortality on farmed fish, other siphonophores including Apolemia uvaria (Båmstedt et al., 1998) and Muggiaea atlantica have been implicated in 


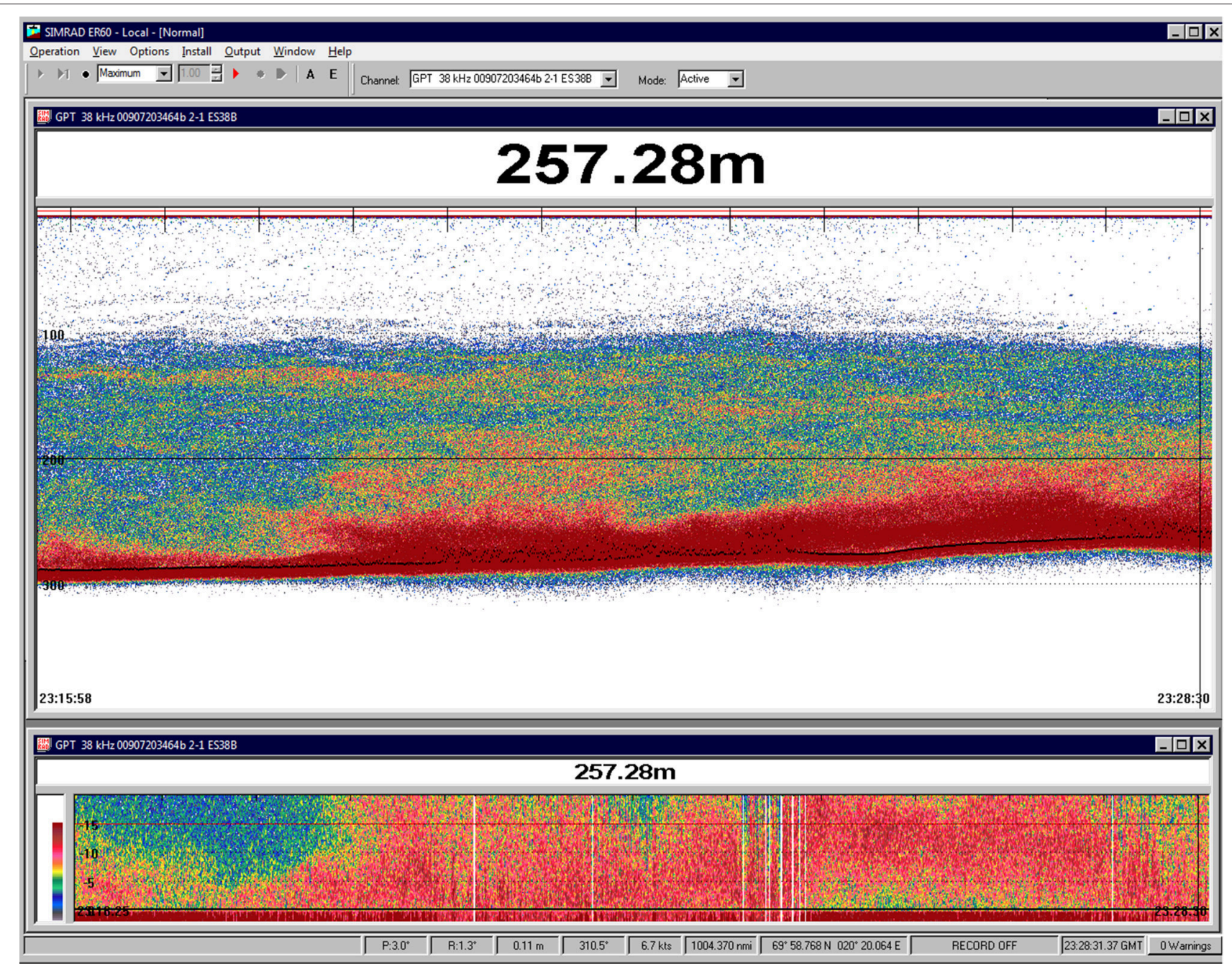

FIGURE 15 | Upper part: Pelagic $38 \mathrm{kHz}$ screendump echogram (Simrad EK60/ER60 system, www.simrad.com/ek60) from the outer part of Lyngen during midnight 26/27 November 2015 (23:15:58-23:28:30 UTC). Lower part: Bottom channel $38 \mathrm{kHz}$ echogram, 0-20 m above the bottom.

killing farmed fish (Fosså et al., 2003) and causing considerable economic losses, together with a number of other cnidarians and even ctenophores (cf. Lucas et al., 2014; Halsband et al., 2017). Aquaculture activity, e.g. salmon farming, is increasing in the north Norwegian fjords and several places there are also important local fisheries for northern shrimp (Pandalus borealis), cod (Gadus morhua, haddock (Melanogrammus aeglefinus), and saithe (Pollachius virens) in the region.

In the Lyngenfjord-Kvænangen area a total of around 12 salmon production sites had live salmonids in their pens (ca. 26,000 tons), at the time of this bloom (Otto Andreassen, pers. comm., Directorate of Fisheries, Norway). The majority of farms were situated in the shallows between the island separating Lyngenfjord and Kvænangen, or in shallow fringe areas away from the basins where the density of siphonophores were high. With the current estimates of siphonophore abundances, particularly in the epipelagic zone, we can conclude that the bloom reported here had little to no direct effect on farmed fish in the region, but overlap between fish farms and siphonophores might not have been high given how the fish farms were located, and no farmed fish mortality due to jellies has been reported. The anomalous conditions reported here lasted for about 5 months and certainly resulted in income loss for local communities along the fjords, although we do not know if such losses have been quantified. It is not inconceivable that abundant Nanomia spp. also could have adverse effects on exposed wild fish, but we know of no such reports yet.

It is also known that ctenophore blooms have caused losses to aquaculture (reviewed in Lucas et al., 2014), but in these northern Norwegian fjords we know of no reports of ctenophore blooms that have caused problems for fish farms or commercial fishing activity.

The combined predatory impact of large numbers of gelatinous predators on the natural zooplankton community can be considerable. The trophic impacts of Nanomia and Beroe are, 
however, likely to be rather different: While Nanomia spp. feed primarily on crustacean zooplankton including copepods and euphausiids (Purcell, 1981, 1997; Robison et al., 1998), Beroe spp. are assumed to feed largely on other ctenophores (reviewed in Purcell, 1991, 1997). Nanomia may thus be in direct competition with fish for the food resources, while the presence of Beroe spp. could theoretically even serve to reduce predation pressure on crustacean zooplankton through trophic cascading.

\section{Concluding Remarks}

Most jellyfish blooms are ephemeral in nature. The rapid population expansions leading to a bloom depend on a series of advantageous events, of which food availability, successful reproduction and high survival rate of the younger stages to adult individuals or colonies are crucial. Environmental conditions including ambient temperature, oxygen levels, and currents are additional factors important in determining bloom success, dispersal, and longevity. For the species with a benthic stage, such as the observed $M$. rotunda, the conditions experienced by the polyps or hydroids may be significant in determining the magnitude of medusa production (Boero et al., 2008). The bloom of the holopelagic physonect siphonophore Nanomia sp. reported herein, appears to be of local origin. A local fisherman reported of a very similar event that occurred $\sim 60$ years ago in the LyngenKvænangen area, and there are also similar reports from other parts of the Northern Atlantic (cf. Rogers, 1976a). The scarcity of these reports suggests that such events may be rare, or are at least rarely observed or reported on.

The current work demonstrates severe contamination of various types of fishing gear, particularly by the siphonophores, leading to greatly reduced fishing efficiency, but it is also possible that wild fish migrated away from the areas with highest densities of these organisms. Increased mortality of farmed fish in the Lyngenfjord-Kvænangen area was not reported during the period of these investigations. One reason could be low overlap between farm locations and high density siphonophore areas, including the tendency of the siphonophores to be particularly abundant in the deeper part of the outer fjord basins.

In this investigation, the acoustics proved to be a valuable technique to track the abundance and distribution of physonect siphonophores, when these organisms were the dominant scatterers in the water column. They are the only gelatinous zooplankton species with a gas-inclusion that allows them to stand out acoustically at the frequencies used in the current work. For non-physonect siphonophores, hydromedusae, scyphomedusae, and ctenophores, their acoustic backscattering is much less efficient. The combination of different approaches including genetics, trawling, traditional taxonomic analyses, and fishers information on the species responsible for the gelatinous blooms, enabled documentation of bloom timing and duration, and possible over-wintering areas for ctenophores, but particularly the physonect siphonophore $N$. cara in the region.

As a precautionary approach, it is important to document such bloom events and to monitor the frequencies of occurrence, abundances and types of species involved and to determine if the ambient environmental conditions during blooms change over time. An improved understanding of potentially harmful gelatinous zooplankton blooms and their effects on local ecosystems is important for future management and development of mitigation measures to minimize ecosystem, aquaculture, and fisheries impact.

\section{ETHICS STATEMENT}

The Institute of Marine Research (IMR) fully adheres to Norwegian and European laws and regulations relevant to Ethics in Science as well as Animal Welfare. The field work on which this study is based, was carried out within the Norwegian animal welfare act guidelines, in accordance with the Animal Welfare Act of 20th December 1974, amended 19th June 2009. Under these laws and regulations there are currently no requirement for an ethical approval of field investigations as described and reported in the current manuscript. The legal and institutional framework within which IMR operate is detailed in OECD (2012, Part III, Chapter 21:373-398).

\section{AUTHOR CONTRIBUTIONS}

TK: conceived the idea to have the story disclosed, analyzed the data, wrote the paper, prepared the figures/tables, and reviewed drafts of the paper; $\mathrm{AH}$ : contributed to analysis of biological material and photos as well as interpretation of genetic results, wrote, and reviewed drafts of the paper. TF: contributed text on the ctenophore Beroe and other zooplankton in North Norwegian fjords and reviewed drafts of the paper; RS-M: was responsible for the genetic analyses, wrote, and reviewed drafts of the paper; PW: contributed on the application of the acoustic backscattering models, wrote, and reviewed drafts of the paper; AA, RL, and EB: were responsible for the field work; scrutinized the acoustic data onboard the vessel, acquired the photo-, video documentation and the biological material for genetic analyses, analyzed the trawl catches, and reviewed drafts of the paper. All authors have agreed to be listed and have approved the submitted version of the manuscript.

\section{FUNDING}

The work was funded by the Ministry of Fisheries and Coastal Affairs through the Institute of Marine Research (IMR), while the Research Council of Norway (RCN) is thanked for the financial support through the project The Arctic Ocean Ecosystem(SI_ARCTIC, RCN 228896). The funders had no role in study design, data collection, and analysis, decision to publish, or in preparation of the manuscript. $\mathrm{AH}$ was supported by the Norwegian Taxonony Initiative (NTI 70184233) and ForBio Research School funding (RCN 248799 and NTI 70184215).

\section{ACKNOWLEDGMENTS}

We thank fisherman Hugo Pedersen from Akkarvik (Arnøya, Troms) for allowing us onboard his vessel and making biological material from his fishing gear available for microscopic 
examination, as well as Gunnar Sætra (Public relations and communications Department, IMR, Tromsø), for photo documentation and help with onboard collection and conservation of biological material. Many thanks to Elise $\mathrm{T}$. Olaussen that made us aware of the misery experienced by the local fishermen. Jarle Mollan (Skjervøy, Troms) is kindly thanked for memorizing key events of historic significance associated with local fisheries in the Lyngen-Kvænangen region. The work conducted by Stig Mæhle (IMR) on the genetic analyses is greatly appreciated. Former IMR colleague Dr. John Dalen, Soundmare,

\section{REFERENCES}

Aksnes, D. L., Dupont, N., Staby, A., Fiksen, Ø., Kaartvedt, S., and Aure, J. (2009). Coastal water darkening and implications for mesopelagic regime shifts in Norwegian fjords. Mar. Ecol. Prog. Ser. 387, 39-49. doi: 10.3354/meps08120

Anderson, V. C. (1950). Sound scattering from a fluid sphere. J. Acoust. Soc. Am. 22, 426-431. doi: 10.1121/1.1906621

Arai, M. N. (1992). Active and passive factors affecting aggregations of hydromedusae: a review. Sci. Mar. 56, 99-108.

Aure, J. (1983). Akvakultur $i$ Troms. Kartlegging av Høvelige Lokaliteter for Fiskeoppdrett: Fisken og Havet; serie B, nr.1. Rapporter og meldinger fra. Fiskeridirektoratets havforskningsinstitutt. Bergen.

Båmstedt, U., Fosså, J. H., Martinussen, M. B., and Fosshagen, A. (1998). Mass occurrence of the physonect siphonophore Apolemia uvaria (Lesueur) in Norwegian waters. Sarsia 83, 79-85. doi: 10.1080/00364827.1998.10413673

Bagøien, E., Kaartvedt, S., Aksnes, D.L., and Eiane, K. (2001). Vertical distribution and mortality of overwintering Calanus. Limnol. Oceanograp. 46, 1494-1510. doi: 10.4319/lo.2001.46.6.1494

Barham, E. G. (1963). Siphonophores and the deep scattering layer. Science 140, 826-828. doi: 10.1126/science.140.3568.826

Barham, E. G. (1966). Deep scattering layer migration and composition: observations from a diving saucer. Science 151, 1399-1403. doi: 10.1126/science.151.3716.1399

Benfield, M. C., Lavery, A. C., Wiebe, P. H., Greene, C. H., Stanton, T. K., and Copley, N. J. (2003). Distributions of physonect siphonulae in the Gulf of Maine and their potential as important sources of acoustic scattering. Can. J. Fish. Aquat. Sci. 60, 759-772. doi: 10.1139/f03-065

Berrill, N. (1930). On the occurrence and habits of the Siphonophore, Stephanomia bijuga (Delle Chiaje). J. Mar. Biol. Assoc. U.K. 16, 753-755. doi: $10.1017 /$ S0025315400073069

Boero, F., Bouillon, J., Gravili, C., Miglietta, M. P., Parsons, T., and Piraino, S. (2008). Gelatinous plankton: irregularities rule the world (sometimes). Mar. Ecol. Prog. Ser. 356, 299-310. doi: 10.3354/meps07368

Brodeur, R. D., Decker, M. B., Ciannelli, L., Purcell, J. E., Bond, N. A., Stabeno, P. J., et al. G.L. (2008). Rise and fall of jellyfish in the eastern Bering Sea in relation to climate regime shifts. Prog. Oceanogr. 77, 103-111. doi: 10.1016/j.pocean.2008.03.017

Brodeur, R. D., Mills, C. E., Overland, J. E., Walters, G. E., and Schumacher, J. D. (1999). Evidence for a substantial increase in gelatinous zooplankton in the Bering Sea, with possible links to climate change. Fish. Oceanogr. 8, 296-306. doi: 10.1046/j.1365-2419.1999.00115.x

Brotz, L., Cheung, W. W. L., Kleisner, K., Pakhomov, E., and Pauly, D. (2012). Increasing jellyfish populations: trends in large marine ecosystems. Hydrobiologia 690, 3-20. doi: 10.1007/s10750-012-1039-7

Browne, E. T., Thompson, I. C., Gamble, F., Herdman, W., Cunningham, J., Beaumont, W., et al. (1898). The fauna and flora of Valencia Harbour on the West Coast of Ireland. Proc. R. Irish Acad. 5, 667-854.

Bucklin, A., Hopcroft, R. R., Kosobokova, K. N., Nigro, L. M., Ortman, B. D., Jennings, R. M., et al. (2010). DNA barcoding of Arctic Ocean holozooplankton for species identification and recognition. Deep Sea Res. II Top. Stud. Oceanogr. 57, 40-48 doi: 10.1016/j.dsr2.2009.08.005

Condon, R. H., Duarte, C. M., Pitt, K. A., Robinson, K. L., Lucas, C. H., Sutherland, K. R., et al. (2013). Recurrent jellyfish blooms are a is gratefully acknowledged for contributing to the sections on underwater acoustics. This work is a contribution to the Barents Sea, Norwegian Sea, and Coastal Zone Ecosystem Programs at IMR.

\section{SUPPLEMENTARY MATERIAL}

The Supplementary Material for this article can be found online at: https://www.frontiersin.org/articles/10.3389/fmars. 2018.00158/full\#supplementary-material consequence of global oscillations. Proc. Nat. Acad. Sci. U.S.A. 110, 1000-1005. doi: 10.1073/pnas.1210920110

Condon, R. H., Graham, W. M., Duarte, C. M., Pitt, K. A., Lucas, C. H., Haddock, S. H. D., et al. (2012). Questioning the rise of gelatinous zooplankton in the world's oceans. Bioscience 62, 160-169. doi: 10.1525/bio.2012. 62.2 .9

Condon, R. H., Steinberg, D. K., Del Giorgio, P. A., Bouvier, T. C., Bronk, D. A., Graham, W. M., et al. (2011). Jellyfish blooms result in a major microbial respiratory sink of carbon in marine systems. Proc. Natl. Acad. Sci. U.S.A. 108, 10225-10230. doi: 10.1073/pnas.1015782108

Cornelius, P. F. (1995). North-West European Thecate Hydroids and Their Medusae: Keys and Notes for Identification of the Species, Vol. 1, Great Britain: Field Studies Council, Linnean Society of London, Estuarine and Coastal Sciences Association.

Costello, J. H., Colin, S. P., Gemmell, B. J., Dabiri, J. O., and Sutherland, K. R. (2015). Multi-jet propulsion organized by clonal development in a colonial siphonophore. Nat. Commun. 6, 8158. doi: 10.1038/ncomms9158

Costello, J. H., and Mianzan, H. W. (2003). Sampling field distributions of Mnemiopsis leidyi (Ctenophora, Lobata): planktonic or benthic methods? J. Plankton Res. 25, 455-459. doi: 10.1093/plankt/25.4.455

Costello, J. H., Sullivan, B. K., Gifford, D. J., Van Keuren, D., and Sullivan, L. J. (2006). Seasonal refugia, shoreward thermal amplification and metapopulation dynamics of the ctenophore Mnemiopsis leidyi in Narragansett Bay, Rhode Island. Limnol. Oceanogr. 51, 1819-1831. doi: 10.4319/lo.2006.51.4.1819

Cunningham, C. W., and Buss, L. W. (1993). Molecular evidence for multiple episodes of paedomorphosis in the family Hydractiniidae. Biochem. Syst. Ecol. 21, 57-69. doi: 10.1016/0305-1978(93)90009-G

Dalen, J., and Løvik, A. (1981). The influence of wind-induced bubbles on echo integration surveys. J. Acoust. Soc. Am. 69, 1653-1659. doi: 10.1121/1.385943.

Dalpadado, P., Ingvaldsen, R. B., Stige, L. C., Bogstad, B., Knutsen, T., Ottersen, G., et al. (2012). Climate effects on Barents Sea ecosystem dynamics. ICES J. Mar. Sci. 69, 1303-1316. doi: 10.1093/icesjms/fss063

Diachok, O. (2001). Interpretation of the spectra of energy scattered by dispersed anchovies. J. Acoust. Soc. Am. 110, 2917-2923. doi: 10.1121/1.1413996

Engås, A. (1994). "The effects of trawl performance and fish behaviour on the catching efficiency of demersal sampling trawls," in Marine Fish Behaviour in Capture and Abundance Estimation, eds A. Fernö and S. Olsen (Oxford: Fishing News Books. Blackwell Science Ltd), 45-68.

Eriksen, E., Prozorkevich, D., Trofimov, A., and Howell, D. (2012). Biomass of scyphozoan jellyfish, and its spatial association with 0-Group fish in the Barents sea. PLoS ONE 7:e33050. doi: 10.1371/journal.pone.0033050

Espeland, S. H., Albretsen, J., Olsen, E. M., and Bodvin, T. (2015). Modelling drift of pelagic offspring: the importance of egg surveys in providing a realistic model initialization. ICES J. Mar. Sci. 72, 2578-2589. doi: 10.1093/icesjms/ fsv134

Falkenhaug, T. (1996). Distributional and seasonal patterns of ctenophores in Malangen, northern Norway. Mar. Ecol. Prog. Ser. 140, 59-70. doi: $10.3354 /$ meps 140059

Falkenhaug, T., Nordby, E., Svendsen, H., and Tande, K. S. (1995). "Impact of advective processes on zooplankton biomass in a North Norwegian fjord system: a comparison between spring and autumn", in Ecology of Fjords and Coastal Waters, eds H. R. Skjoldal, C. Hopkins, K. E. Erikstad, and H. P. Leinaas (Amsterdam: Elsevier Science), 403-415. 
Falkenhaug, T., Tande, K. S., and Semenova, T. (1997a). Diel, seasonal and ontogenetic variations in the vertical distributions of four marine copepods. Mar. Ecol. Prog. Ser. 149, 105-119.

Falkenhaug, T., Tande, K. S., and Timonin, A. (1997b). Spatio-temporal patterns in the copepod community in Malangen, Northern Norway. J. Plankton Res. 19, $449-468$.

Folmer, O., Black, M., Hoeh, W., Lutz, R., and Vrijenhoek, R. (1994). DNA primers for amplification of mitochondrial cytochrome $\mathrm{c}$ oxidase subunit I from diverse metazoan invertebrates. Mol. Mar. Biol. Biotechnol. 3, 294-299.

Foote, K. G., Knudsen, H. P., Vestnes, G., MacLennan, D. N., and Simmonds, E. J. (1987). Calibration of Acoustic Instruments for Fish Density Estimation: A Practical Guide. ICES Cooperative Research Report No. 144.

Fosså, J. H., Flood, P. R., Olsen, A. B., and Jensen, F. (2003). "Små og usynlige, men plagsomme maneter av arten Muggiaea atlantica (Small and invisible, but troublesome jellyfish of the species Muggiaea atlantica)," in Fisken og havet, særnr. 2, eds L. Asplin and E. Dahl (Bergen), 99-103.

Godø, O. R., Patel, R., and Pedersen, G. (2009). Diel migration and swimbladder resonance of small fish: some implications for analyses of multifrequency echo data. ICES J. Mar. Sci. 66, 1143-1148. doi: 10.1093/icesjms/ fsp098

Godø, O. R., Valdemarsen, J. W., and Engås, A. (1993). Comparison of efficiency of standard and experimental juvenile gadoid sampling trawls. ICES Mar. Sci. Symp. 196, 196-201.

Gorska, N., Ona, E., and Korneliussen, R. (2004). On Acoustic Multi-Frequency Species Identification and Separation of Atlantic mackerel, Norwegian Spring Spawn Herring and Norway Pout. ICES CM 2004/R:18. 1-9.

Graham, W. M., Pagès, F., and Hamner, W. M. (2001). A physical context for gelatinous zooplankton aggregations: a review. Hydrobiologia 451, 199-212. doi: 10.1023/A:1011876004427

Haberlin, D., Mapstone, G., Mcallen, R., Mcevoy, A. J., and Doyle, T. K. (2016). Diversity and occurrence of siphonophores in Irish coastal waters. Biol. Environ. Proc. R. Irish Acad. 116B, 119-129. doi: 10.3318/bioe.2016.12

Halpern, B. S., Walbridge, S., Selkoe, K. A., Kappel, C. V., Micheli, F., D’Agrosa, C., et al. (2008). A global map of human impact on marine ecosystems. Science 319, 948-952. doi: 10.1126/science.1149345

Halsband, C., Majaneva, S., Hosia, A., Emaus, P. A., Gaardsted, F., Zhou, Q., et al. (2017). Jellyfish summer distribution, diversity and impact on fish farms in a Nordic fjord. Mar. Ecol. Prog. Ser. doi: 10.3354/meps12274

Hopkins, C. C. E., Tande, K. S., and Grønvik, S. (1984). Ecological investigations of the zooplankton community of Balsfjorden, Northern Norway: an analysis of growth and overwintering tactics in relation to niche and environment in Metridia longa (Lubbock), Calanus finmarchicus (Gunnerus), Thysanoessa inermis (Krøyer) and T. raschi (M. Sars). J. Exp. Mar. Biol. Ecol. 82, 77-99. doi: 10.1016/0022-0981(84)90140-0

Hosia, A., Augustin, C. B., Dinasquet, J., Granhag, L., Paulsen, M. L., Riemann, L., et al. (2015). Autumnal bottom-up and top-down impacts of Cyanea capillata: a mesocosm study. J. Plankton Res. 37, 1042-1055. doi: 10.1093/plankt/fbv046

Hosia, A., and Båmstedt, U. (2007). Seasonal changes in the gelatinous zooplankton community and hydromedusa abundances in Korsfjord and Fanafjord, western Norway. Mar. Ecol. Prog. Ser. 351, 113-127. doi: $10.3354 /$ meps 07148

Hosia, A., and Båmstedt, U. (2008). Seasonal abundance and vertical distribution of siphonophores in western Norwegian fjords. J. Plankton Res. 30, 951-962. doi: 10.1093/plankt/fbn045

Hosia, A., Stemmann, L., and Youngbluth, M. (2008). Distribution of netcollected planktonic cnidarians along the northern Mid-Atlantic Ridge and their associations with the main water masses. Deep Sea Res. II Top. Stud. Oceanogr. 55, 106-118. doi: 10.1016/j.dsr2.2007.09.007

Huse, I., and Korneliussen, R. (2000). Diel variation in acoustic density measurements of overwintering herring (Clupea harengus L.). ICES J. Mar. Sci. 57, 903-910. doi: 10.1006/jmsc.2000.0577

Huse, I., and Ona, E. (1996). Tilt angle distribution and swimming speed of overwintering Norwegian spring-spawning herring. ICES J. Mar. Sci. 53, 863-873. doi: 10.1006/jmsc.1996.9999

ICES (2015a). Calibration of Acoustic Instruments, May 2015. Cooperative Research Report No. 326

ICES (2015b). Manual for International Pelagic Surveys (IPS). Series of ICES Survey Protocols SISP 9 - IPS. 1-92.
Jakobsson, M., Mayer, L. A., Coakley, B., Dowdeswell, J. A., Forbes, S., Fridman, B., et al. (2012). The International Bathymetric Chart of the Arctic Ocean (IBCAO) Version 3.0. Geophys. Res. Lett. 39:L12609. doi: 10.1029/2012GL052219

Jenssen, O. A. (2006). Deglasiasjon og Sedimentasjonsmiljø i Lyngen og Storfjorden. Mastergradsoppgave i arktisk marin geologi og geofysikk, Universitetet i Tromsø, Troms.

Kirkpatrick, P. A., and Pugh, P. R. (1984). Siphonophores and Velellids. Synopsis of the British Fauna 29, 1-154.

Knudsen, H. P. (2009). Long-term evaluation of scientific-echosounder performance. ICES J. Mar. Sci. 66, 1335-1340. doi: 10.1093/icesjms/fsp025

Korneliussen, R. J., Heggelund, Y., Eliassen, I. K., and Johansen, G. O. (2009). Acoustic species identification of schooling fish. ICES J. Mar. Sci. 66, 1111-1118. doi: 10.1093/icesjms/fsp119

Korneliussen, R. J., Heggelund, Y., Macaulay, G. J., Patel, D., Johnsen, E., and Eliassen, I. K. (2016). Acoustic identification of marine species using a feature library. Methods Oceanogr. 17, 187-205. doi: 10.1016/j.mio.2016.09.002

Korneliussen, R. J., and Ona, E. (2003). Synthetic echograms generated from the relative frequency response. ICES J. Mar. Sci. 60, 636-640. doi: 10.1016/S1054-3139(03)00035-3

Korneliussen, R. J., Ona, E., Eliassen, I., Heggelund, Y., Patel, R., Godø, O. R., et al. (2006). "The large scale survey system - LSSS," in Proceedings of the 29th Scandinavian Symposium on Physical Acoustics (Ustaoset).

Kvendbø Hegstad, S. M. (2014). Post-glacial Sedimentary Processes and Slope Instabilities off Nordnesfjellet, Lyngenfjorden, Northern Norway. Master's thesis in Geology, Faculty of Science and Technology; Department of Geology; University of Tromsø.

Larsen, L. H. (1997). Soft-bottom macro invertebrate fauna of North Norwegian coastal waters with particular reference to sill-basins. Part one: Bottom topography and species diversity. Hydrobiologia 355, 101-113. doi: 10.1023/A:1003013725472

Lavery, A. C., Wiebe, P. H., Stanton, T. K., Lawson, G. L., Benfield, M. C., and Copley, N. (2007). Determining dominant scatterers of sound in mixed zooplankton populations. J. Acoust. Soc. Am. 122, 3304-3326. doi: $10.1121 / 1.2793613$

Lebrato, M., De Jesus Mendes, P., Steinberg, D. K., Cartes, J. E., Jones, B. M., Birsa, L. M., et al. (2013). Jelly biomass sinking speed reveals a fast carbon export mechanism. Limnol. Oceanogr. 58, 1113-1122. doi: 10.4319/lo.2013.58.3.1113

Licandro, P., Blackett, M., Fischer, A., Hosia, A., Kennedy, J., Kirby, R. R., et al. (2015). Biogeography of jellyfish in the North Atlantic, by traditional and genomic methods. Earth Syst. Sci. Data 7, 173-191. doi: 10.5194/essd-7-173-2015

Lucas, C. H., Gelcich, S., and Uye, S.-I. (2014). "Living with jellyfish management and adaptation strategies," in Jellyfish Blooms, eds K. A. Pitt and C. H. Lucas (Netherlands: Springer), 129-150. doi: 10.1007/978-94-007-7015-7_6

Mackie, G. O., Pugh, P. R., and Purcell, J. E. (1987). Siphonophore biology. $A d v$. Mar. Biol. 24, 97-262. doi: 10.1016/S0065-2881(08)60074-7

Mackie, O. G. (1985). Midwater macroplankton of British Columbia studied by submersible PISCES IV. J. Plankton Res. 7, 753-777. doi: $10.1093 /$ plankt/7.6.753

MacLennan, D. N., Fernandes, P. G., and Dalen, J. (2002). A consistent approach to definitions and symbols in fisheries acoustics. ICES J. Mar. Sci. 59, 365-369. doi: 10.1006/jmsc.2001.1158

Majaneva, S., Berge, J., Renaud, P. E., Vader, A., Stübner, E., Rao, A. M., et al. (2013). Aggregations of predators and prey affect predation impact of the Arctic ctenophore Mertensia ovum. Mar. Ecol. Prog. Ser. 476, 87-100. doi: $10.3354 /$ meps 10143

Manko, M. K., and Panasiuk-Chodnicka, A. A., and Zmijewska, M. I. (2015). Pelagic coelenterates in the Atlantic sector of the Arctic Ocean - species diversity and distribution as water mass indicators. Oceanol. Hydrobiol. Stud. 44, 466-479. doi: 10.1515/ohs-2015-0044.

Mapstone, G. M. (2009). Siphonophora (Cnidaria, Hydrozoa) of Canadian Pacific waters. Ottawa, ON: NRC Research Press.

Matthews, J. B. L., and Heimdal, B. R. (1980). "Pelagic productivity and food chains in fjord systems", in Fjord oceanography, NATO Conference Series, IV, Marine Science, eds H. J. Freeland, D. M. Farmer, and C. D. Levings (New York, NY; London: Plenum Press), 377-398.

Medwin, H., and Clay, C. S. (1998). Fundamentals of Acoustical Oceanography. (San Diego, CA: Academic Press) 1-712. 
Mehl, S., Aglen, A., Berg, E., Dingsør, G., and Korsbrekke, K. (2015). Akustisk Mengdemåling av sei, Kysttorsk og hyse, Finnmark - Møre, Hausten 2015 (In English: Acoustic Abundance of Saithe, Coastal Cod and Haddock Finnmark Møre Autumn 2015). Survey report. Institute of Marine Research.

Mills, C. E. (1995). Medusae, siphonophores, and ctenophores as planktiovorous predators in changing global ecosystems. ICES J. Mar. Sci. 52, 575-581. doi: 10.1016/1054-3139(95)80072-7

Mills, C. E. (2001). Jellyfish blooms: are populations increasing globally in response to changing ocean conditions? Hydrobiologia 451, 55-68. doi: 10.1023/A:1011888006302

Nedreaas, K., and Smedstad, O. M. (1987). Abundance and Distribution of Postlarvae in the 0-Group Saithe Survey in the North Sea and the Northeast Arctic in 1986 and 1987. ICES C.M. 1987/G31. 1-27.

OECD (2012). OECD Review of Fisheries 2011: Policies and Summary Statistics. OECD Publishing

Oguz, T., Salihoglu, B., Moncheva, S., and Abaza, V. (2012). Regional peculiarities of community-wide trophic cascades in strongly degraded Black Sea food web. J. Plankton Res. 34, 338-343. doi: 10.1093/plankt/ fbs002

Pedersen, T., Ramsvatn, S., Nilssen, E. M., Nilsen, M., Morissette, L., Ivarjord, T., et al. (2015). Species diversity affects ecosystem structure and mass flows in fjords. Reg. Stud. Mar. Sci. 3, 205-215. doi: 10.1016/j.rsma.2015. 10.007

Pickwell, G. V., Barham, E. G., and Wilton, J. W. (1964). Carbon monoxide production by a bathypelagic siphonophore. Science 144, 860-862. doi: $10.1126 /$ science. 144.3620 .860

Pitt, K. A., Budarf, A. C., Browne, J. G., and Condon, R. H. (2014). "Bloom and bust: why do blooms of jellyfish collapse?," in Jellyfish Blooms, eds K. A. Pitt and C. H. Lucas (Dordrecht: Springer), 79-103.

Pitt, K. A., Welsh, D. T., and Condon, R. H. (2009). Influence of jellyfish blooms on carbon, nitrogen and phosphorus cycling and plankton production. Hydrobiologia 616, 133-149. doi: 10.1007/s10750-008-9584-9

Purcell, J. E. (1981). Dietary composition and diel feeding patterns of epipelagic siphonophores. Mar. Biol. 65, 83-90. doi: 10.1007/BF00397071

Purcell, J. E. (1991). A review of cnidarians and ctenophores feeding on competitors in the plankton. Hydrobiologia 216, 335-342. doi: $10.1007 / \mathrm{BF} 00026483$

Purcell, J. E. (1997). Pelagic cnidarian and ctenophores as predators: selective predation, feeding rates, and effects on prey populations. Annales de l'Institut Océanographique 73, 125-137.

Purcell, J. E., Hopcroft, R. R., Kosobokova, K. N., and Whitledge, T. E. (2010). Distribution, abundance, and predation effects of epipelagic ctenophores and jellyfish in the western Arctic Ocean. Deep Sea Res. II Top. Stud. Oceanogr. 57, 127-135. doi: 10.1016/j.dsr2.2009.08.011

Purcell, J. E., Uye, S.-I., and Lo, W. T. (2007). Anthropogenic causes of jellyfish blooms and their direct consequences for humans: a review. Mar. Ecol. Prog. Ser. 350, 153-174. doi: 10.3354/meps07093

Raskoff, K. A., Purcell, J. E., and Hopcroft, R. R. (2005). Gelatinous zooplankton of the Arctic Ocean: in situ observations under the ice. Polar Biol. 28, 207-217. doi: $10.1007 / \mathrm{s} 00300-004-0677-2$

R Core Team (2015). R: A Language and Environment for Statistical Computing. A Welch Two-Sample t-Test Using the Statistical Software Package R v.3.2.3 (201512-10). Vienna: R Foundation for Statistical Computing. Available online at: https://www.R-project.org/

Richardson, A. J., Bakun, A., Hays, G. C., and Gibbons, M. J. (2009). The jellyfish joyride: causes, consequences and management responses to a more gelatinous future. Trends Ecol. Evol. 24, 312-322. doi: 10.1016/j.tree.2009.01.010

Robison, B. H., Reisenbichler, K. R., Sherlock, R. E., Silguero, J. M. B., and Chavez, F. P. (1998). Seasonal abundance of the siphonophore, Nanomia bijuga, in Monterey Bay. Deep-Sea Res. II 45, 1741-1751. doi: 10.1016/S0967-0645(98)80015-5

Rogers, C. A. (1976a). Impact of Autumn-Winter Swarming of a Siphonophore ("Lipo") on Fishing in Coastal Waters of New England. Environmental Impact Report 1-76. National Marine Fisheries Service, Northeast Fisheries Center. $1-28$

Rogers, C. A. (1976b). Reduction in Abundance of Siphonophores on New England Fishing Grounds in Spring 1976. Environmental Impact Report 2-76. National Marine Fisheries Service Northeast Fisheries Center Narragansett. 1-5.
Rogers, C. A., Biggs, D. C., and Cooper, R. A. (1978). Aggregation of the siphonophore Nanomia cara in the Gulf of Maine: observations from a submersible. Fish. Bull. 76, 281-284.

Ronowicz, M., Kuklinski, P., and Mapstone, G. M. (2015). Trends in the diversity, distribution and life history strategy of Arctic hydrozoa (Cnidaria). PLoS ONE 10:e0120204. doi: 10.1371/journal.pone.01 20204

Russell, F. S. (1933). The seasonal distribution of macroplankton as shown by catches in the 2-meter Stramin ring-trawl in off-shore waters of Plymouth. J. Mar. Biol. Assoc. U.K. 19, 73-82. doi: 10.1017/S00253154000 5579X

Sanz-Martín, M., Pitt, K. A., Condon, R. H., Lucas, C. H., Novaes De Santana, C., and Duarte, C. M. (2016). Flawed citation practices facilitate the unsubstantiated perception of a global trend toward increased jellyfish blooms. Glob. Ecol. Biogeogr. 25, 1039-1049. doi: 10.1111/geb. 12474

Schlitzer, R. (2015). Ocean Data View. Available online at: http://odv.awi.de.

Schuchert, P. (2001). Hydroids of Greenland and Iceland: (Cnidaria, Hydrozoa), Vol 53. Danish Polar Center.

Siferd, T. D., and Conover, R. J. (1992). An opening-closing plankton net for horizontal sampling under polar sea-ice. Sarsia 76, 273-277. doi: 10.1080/00364827.1992.10413484

Småge, S. B., Brevik, Ø. J., Frisch, K., Watanabe, K., Duesund, H., and Nylund, A. (2017). Concurrent jellyfish blooms and tenacibaculosis outbreaks in Northern Norwegian Atlantic salmon (Salmo salar) farms. PLoS ONE 12:e0187476. doi: 10.1371/journal.pone.0187476

Svendsen, H. (1995). "Physical oceanography of coupled fjordcoast systems in northern Norway with special focus on frontal dynamics and tides," in Ecology of Fjords and Coastal Waters, eds H. R. Skjoldal, C. Hopkins, K. E. Erikstad, and H. P. Leinaas (Amsterdam: Elsevier Science), 149-164.

Swanberg, N., and Båmstedt, U. (1991). Ctenophora in the Arctic: the abundance, distribution and predatory impact of the cydippid ctenophore Mertensia ovum (Fabricius) in the Barents Sea. Polar Res. 10, 507-524. doi: $10.3402 /$ polar.v10i2.6762

Sweetman, A. K., and Chapman, A. (2015). First assessment of flux rates of jellyfish carcasses (jelly-falls) to the benthos reveals the importance of gelatinous material for biological C-cycling in jellyfish-dominated ecosystems. Front. Mar. Sci. 2:47. doi: $10.3389 /$ fmars.2015.00047

Sweetman, A. K., Smith, C. R., Dale, T., and Jones, D. O. B. (2014). Rapid scavenging of jellyfish carcasses reveals the importance of gelatinous material to deep-sea food webs. Proc. R. Soc. B Biol. Sci. 281:20142210. doi: $10.1098 / \mathrm{rspb} .2014 .2210$

Trevorrow, M. V., Mackas, D. L., and Benfield, M. C. (2005). Comparison of multifrequency acoustic and in situ measurements of zooplankton abundance in Knight Inlet, British Columbia. J. Acoust. Soc. Am. 117, 3574-3588. doi: $10.1121 / 1.1920087$

Warren, J. D., Stanton, T. K., Benfield, M. C., Wiebe, P. H., Chu, D., and Sutor, M. (2001). In situ measurements of acoustic target strengths of gas-bearing siphonophores. ICES J. Mar. Sci. 58, 740-749. doi: 10.1006/jmsc.2001.1047

Wassmann, P., Duarte, C. M., Agusti, S., and Sejr, M. K. (2011). Footprints of climate change in the Arctic marine ecosystem. Glob. Change Biol. 17, 1235-1249. doi: 10.1111/j.1365-2486.2010.02311.x

Wassmann, P., Reigstad, M., Øygarden, S., and Rey, F. (2000). Seasonal variation in hydrography, nutrients, and suspended biomass in a subarctic fjord: applying hydrographic features and biological markers to trace water masses and circulation significant for phytoplankton production. Sarsia 85, 237-249. doi: 10.1080/00364827.2000.10414576

Wassmann, P., Svendsen, H., Keck, A., and Reigstad, M. (1996). Selected aspects of the physical oceanography and particle fluxes in fjords of northern Norway. $J$. Mar. Syst. 8, 53-71. doi: 10.1016/0924-7963(95)00037-2

West, E., Welsh, D., and Pitt, K. (2009). Influence of decomposing jellyfish on the sediment oxygen demand and nutrient dynamics. Hydrobiologia 616, 151-160. doi: 10.1007/s10750-008-9586-7

Wiebe, P. H., Morton, A. W., Bradley, A. M., Backus, R. H., Craddock, J. E., Barber, V., et al. (1985). New developments in the MOCNESS, an apparatus for sampling zooplankton and micronekton. Mar. Biol. 87, 313-323. doi: $10.1007 / \mathrm{BF} 00397811$ 
Williams, R., and Conway, D. V. P. (1981). Vertical distribution and seasonal abundance of Aglantha digitale (O.F. Müller) (Coelenterata: Trachymedusae) and other planktonic coelenterates in the northeast Atlantic Ocean. J. Plankton Res. 3, 633-643. doi: 10.1093/plankt/ 3.4.633

Zedel, L., Knutsen, T., and Patro, R. (2003). Acoustic Doppler current profiler observations of herring movement. ICES J. Mar. Sci. 60, 846-859. doi: 10.1016/S1054-3139(03)00067-5

Zhang, Z., Schwartz, S., Wagner, L., and Miller, W. (2000). A greedy algorithm for aligning DNA sequences. J. Comput. Biol. 7, 203-214. doi: $10.1089 / 10665270050081478$
Conflict of Interest Statement: The authors declare that the research was conducted in the absence of any commercial or financial relationships that could be construed as a potential conflict of interest.

Copyright (c) 2018 Knutsen, Hosia, Falkenhaug, Skern-Mauritzen, Wiebe, Larsen, Aglen and Berg. This is an open-access article distributed under the terms of the Creative Commons Attribution License (CC BY). The use, distribution or reproduction in other forums is permitted, provided the original author(s) and the copyright owner are credited and that the original publication in this journal is cited, in accordance with accepted academic practice. No use, distribution or reproduction is permitted which does not comply with these terms. 